\title{
Morphodynamics and Evolution of Estuarine Sandspits along the Bight of Benin Coast, West Africa
}

\author{
Stephan Korblah Lawson ${ }^{1, *(\mathbb{D}, \text { Hitoshi Tanaka }}{ }^{1}$, Keiko Udo ${ }^{2}$, Nguyen Trong Hiep ${ }^{1} \mathbb{D}$ and Nguyen Xuan Tinh ${ }^{1} \mathbb{C}$ \\ 1 Department of Civil and Environmental Engineering, Tohoku University, Aoba 6-6-06, Sendai 980-8579, Japan; \\ hitoshi.tanaka.b7@dc.tohoku.ac.jp (H.T.); nguyen.hiep.trong.p5@dc.tohoku.ac.jp (N.T.H.); \\ nguyen.xuan.tinh.c5@tohoku.ac.jp (N.X.T.) \\ 2 International Research Institute of Disaster Science, Tohoku University, Aoba 4681-1, Sendai 980-8572, Japan; \\ udo@irides.tohoku.ac.jp \\ * Correspondence: lawson.stephan.korblah.s2@dc.tohoku.ac.jp
}

Citation: Lawson, S.K.; Tanaka, H.; Udo, K.; Hiep, N.T.; Tinh, N.X. Morphodynamics and Evolution of Estuarine Sandspits along the Bight of Benin Coast, West Africa. Water 2021, 13, 2977. https://doi.org/ $10.3390 / w 13212977$

Academic Editors: Maria Mimikou and Achim A. Beylich

Received: 30 August 2021

Accepted: 19 October 2021

Published: 21 October 2021

Publisher's Note: MDPI stays neutral with regard to jurisdictional claims in published maps and institutional affiliations.

Copyright: (c) 2021 by the authors. Licensee MDPI, Basel, Switzerland. This article is an open access article distributed under the terms and conditions of the Creative Commons Attribution (CC BY) license (https:// creativecommons.org/licenses/by/ $4.0 /)$.

\begin{abstract}
It is well known that estuarine systems are significantly affected by hydrodynamic conditions such as river discharge, storm surges, waves and tidal conditions. In addition to this, human interferences through developmental projects have the capability of disrupting the natural morphological processes occurring at estuaries. In West Africa, the goal to improve standards of living through large-scale dam construction, offshore ports and coastal erosion countermeasures has triggered alarming changes in the morphodynamics of estuarine systems. The estuaries at the Volta River mouth (Ghana) and "Bouche du Roi" inlet (Benin), located along the Bight of Benin coast, West Africa, were selected as two case study sites to examine their long-term morphodynamics and sandspit evolution. In this study, we primarily analyzed estuarine morphology using remotely sensed images acquired from 1984 to 2020 . We further estimated the longshore sediment transport for this region using results from the image analysis and the depth of active sediment motion. Our results reveal that the longshore sediment transport rates for this region are in the magnitude of $10^{5}-10^{6} \mathrm{~m}^{3} /$ year. Comparative analysis with other estuaries and sandy coasts suggests that the longshore sediment transport along this coast has one of the largest rates estimated in the world.
\end{abstract}

Keywords: estuarine systems; river mouth; tidal inlet; longshore sediment transport; morphodynamics; satellite image analysis; sandspit; coastal erosion; morphological evolution; Bight of Benin

\section{Introduction}

Estuarine systems are among the most essential ecological environments in the world and support not only socio-economic growth but also the biodiversity of the natural environment [1-3]. The morphological evolution of estuarine systems and the forces driving this evolution have been of interest to coastal researchers, especially at river mouths and tidal inlets [4-10]. The morphodynamics of estuarine systems, i.e., wave climate variability, sediment supply, tidal exchange and river discharge, controls evolutionary processes and therefore requires a thorough understanding through extensive research [11]. Moreover, assessment of the impact of human interferences on estuarine morphology is of great importance to distinguish between naturally and artificially induced evolutions. Anthropogenic activities which include dam construction, dredging works and coastal structures around estuarine systems are undoubtedly aimed towards improving the socioeconomic conditions in and around these areas. However, these activities could result in unforeseen knock-on effects in estuarine environments which necessitates identifying and predicting these impacts [12-14].

A prominent geological feature at some estuaries is the development of sandspits which have a significant impact on the morphological evolutions ensuing at such locations. These geological features provide a great variety of benefits such as protection from storm 
surges and floods, tourism, settlements and sea turtle nesting [15]. Without proper management, the development of sandspits may result in the closure or migration of river mouths or tidal inlets at estuaries. Sandspits are basically formed by deposited sediment driven under the combined effect of wave action, river discharge and longshore and cross-shore currents $[16,17]$. Variations in the form and complexity of sandspits depend on the environmental conditions and geological setting of the location where they develop [18]. Historical sandspit dynamics and predicted dynamics through numerical modeling have been examined extensively all over the world. In recent years, access to high-resolution aerial and satellite images for many estuaries has intensified long-term analysis on sandspit variability, growth and their associated morphological evolution [19-22]. A better understanding of historical sandspit morphological evolution enables future predictions using results from these analyses. Sandspit numerical simulations are essentially focused on describing the formation processes and examining the influence of hydrodynamic processes on their growth or variability [23-28].

The Bight of Benin is an open bay within the Gulf of Guinea in West Africa. Its boundaries span from the southeastern part of Ghana to the southwestern part of Nigeria (Figure 1). Incessant coastal erosion along the Bight of Benin coast has disrupted socioeconomic activities and displaced several coastal communities in the region. Quantification of coastal erosion rates and shoreline variations along this coast has been comprehensively investigated [29-32]. These studies have successfully identified the most vulnerable coastal zones undergoing severe erosion under the influence of prevailing hydrodynamic conditions, climate change and the impact of human activities. Along the Bight of Benin, estuarine systems are subjected to both naturally and artificially induced morphological evolutions. A predominant factor in these evolutions are those caused by human interferences through coastal protection structures, and dam and offshore port construction $[30,33,34]$. In terms of estuarine sandspits, Anthony [35] tentatively described the barrier dynamics in the Bight of Benin and the development of the sandspits at the Volta River mouth in Ghana and the Senegal River mouth in Senegal. In addition, Laibi et al. [36] examined the dynamics of the "Bouche du Roi" inlet in Benin before and after the construction of a large-scale dam using Landsat satellite images.

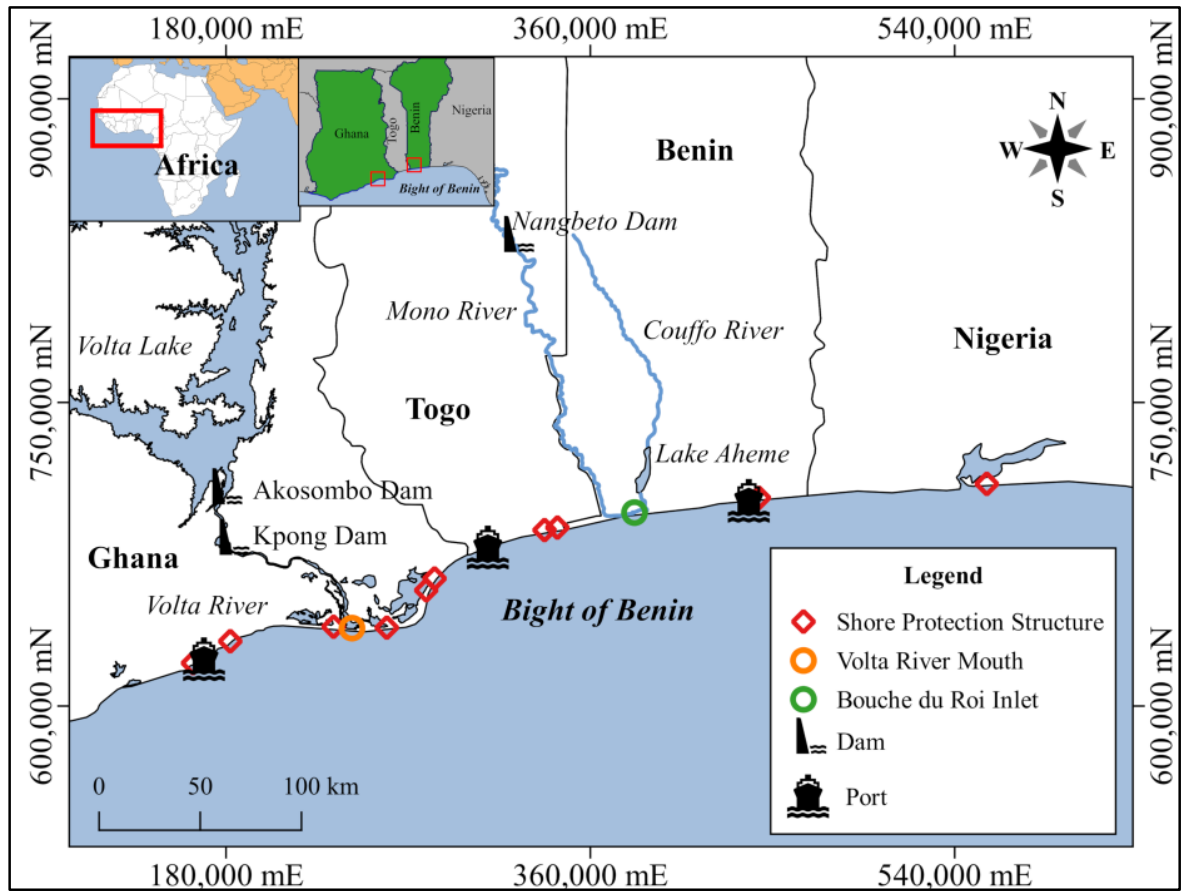

Figure 1. The Bight of Benin coastline in West Africa, and the location of some major engineering infrastructures within the study area. 
In this study, we performed long-term analysis to investigate estuarine sandspit evolutions at two selected estuaries along the Bight of Benin in West Africa. The selected study areas were the estuaries at the Volta River mouth in Ghana and the "Bouche du Roi" inlet in Benin (Figure 1). Since the morphological evolutions of sandspits are driven by wave climate, longshore and/or cross-shore sediment transport, river discharge, tidal conditions and human interferences, we sought to quantify the sandspit growth rates and longshore sediment transport along the Bight of Benin coast. We also examined the characteristic hydrodynamic conditions at these estuaries and their influence on coastal morphodynamics. Furthermore, we investigated the impact of engineering works (shore protection structures, estuary/river dredging, dam and port constructions) on estuarine morphology along this coast. A comprehensive understanding of the morphodynamics and evolution of estuarine systems helps to identify potential developmental projects for these areas and their impact on morphological processes.

To achieve these goals, this study employed the use of historical satellite images from 1984 to 2020 which were acquired from multiple sources (Landsat, Sentinel-2 and Google Earth). Sandspit growth and longshore sediment transport rates (LSTR) were calculated using an analytical model governed by the conservation of sand volume (Sections 3.1 and 3.2). A modified version of the sand volume conservation equation by Duc Anh et al. [37] was adopted to establish a relationship between sandspit growth rates and the width of the sandspit (Section 3.3). Estimated morphodynamic parameters in this study were compared with other estuaries and sandy coasts in the world using results from previous studies (Section 4.1). We further discuss the impact of dam construction and shore protection structures on estuarine morphology and propose future management options for the Bight of Benin coast (Section 4.2).

\section{Materials and Methods}

\subsection{Study Areas}

\subsubsection{The Volta River Mouth, Ghana}

The Volta River mouth is located along the southeastern coast of Ghana which forms part of the downdrift deflected Volta Delta System (Figure 2a). The river mouth drains the Volta basin into the Gulf of Guinea with an approximate catchment area of $400,000 \mathrm{~km}^{2}$ and a river network of about $1500 \mathrm{~km}$. The river basin falls within six West African countries, namely, Mali, Burkina Faso, Ivory Coast, Ghana, Togo and Benin. The Volta Delta is among the three largest deltas in West Africa with the others being the Senegal Delta and the Niger Delta. Present at the river mouth are two sandspits that are involved in controlling the morphodynamics within the estuary (Figure 2b). A typical example is the west to east elongation of the updrift sandspit that leads to narrowing of the river mouth. However, this morphological activity has been halted by the construction of a jetty and groyne system on the western side of the river mouth. These countermeasures were part of the Ada Sea Defence Project (ASDP) executed from 2012 to 2016 (Figure 2b).
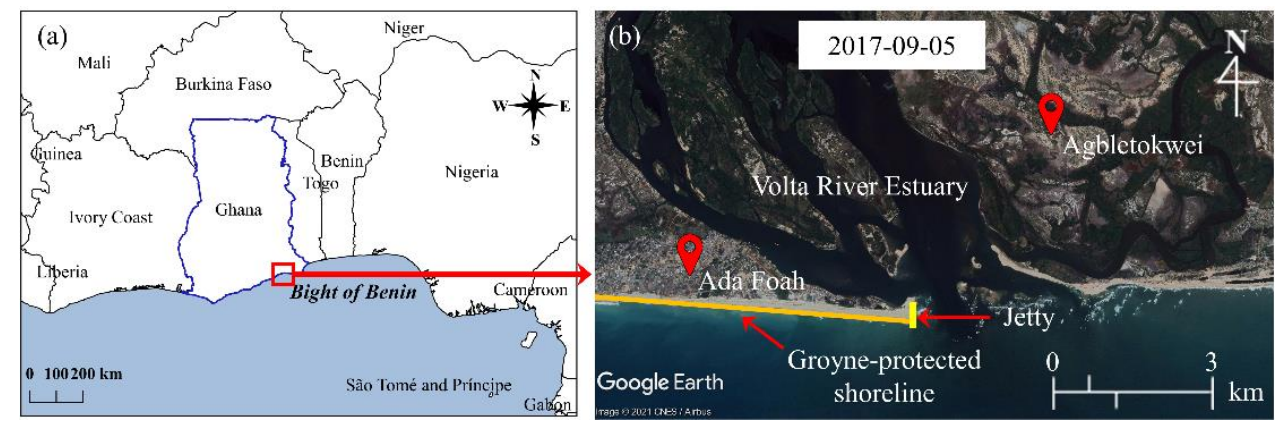

Figure 2. (a) Location of the Volta River mouth in Ghana. (b) The completed Ada Sea Defence Project (ASDP) on the western side of the river mouth. 
The Akosombo and Kpong dams are two hydro-electric dams located about $65 \mathrm{~km}$ and $45 \mathrm{~km}$ upstream of the river mouth, respectively. River discharge datasets from 1936 to 2018 were acquired from the Global Runoff Data Centre (GRDC) and the Volta River Authority (VRA). The GRDC data (1936-1984) corresponded to measurements from the Senchi Gauge Station (located $54 \mathrm{~km}$ upstream of the river mouth), whereas those of the VRA were measurements from the Kpong Dam. Before construction of the dams, the Volta River recorded mean monthly river discharges of over $4000 \mathrm{~m}^{3} / \mathrm{s}$. However, dam operations have seen a mean monthly river discharge below $2000 \mathrm{~m}^{3} / \mathrm{s}$ (Figure 3a). In addition, dam regulation has resulted in a drastic reduction in sediment supply to the river mouth from $180 \times 10^{6}$ to $13 \times 10^{6} \mathrm{~m}^{3} /$ year [38]. This alteration in the river sediment supply is believed to be among several factors exacerbating coastal erosion in the downdrift section of the river mouth [34].
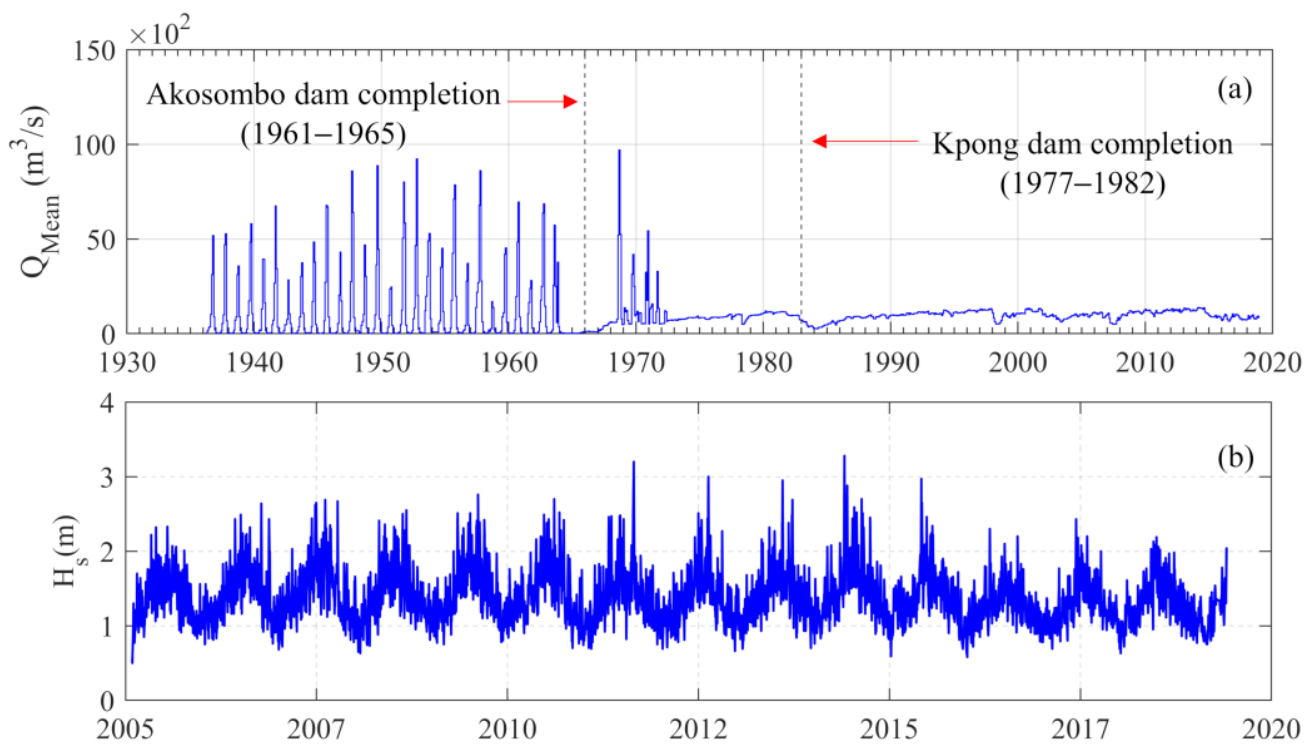

Figure 3. (a) Monthly averaged river discharge at the Senchi Station and Kpong Dam (1936-2018). (b) Significant wave heights for the Volta River mouth extracted from the WaveWatch III model (2005-2019).

The estuary at the Volta River mouth is a wave-dominated estuary. The high wave energies recorded at the river mouth are influential on beach and sandspit evolution. Wave information was obtained from the WaveWatch III model from 2005 to 2019 (Figure 3b). The data were collected at an offshore distance of about $60 \mathrm{~km}$ from the river mouth. Figure 4 also shows the offshore wave height $\left(\mathrm{H}_{\text {rep }}\right)$, period $\left(\mathrm{T}_{\text {rep }}\right)$ and direction $\left(\theta_{\text {rep }}\right)$. In this study area, wave heights approaching the coastline are influenced by the West African Monsoon. From March to October, the wave heights are affected by the Southwest Trade Winds originating from the Atlantic Ocean, and the remaining months of the year are affected by the Northeast Trade Winds from the Sahara Desert. Figure 4 also shows the shore-normal direction of the shoreline with an angle of about $180^{\circ}$. The wave incidence on this rectilinear coastline varies between $15^{\circ}$ and $20^{\circ}$ with dominant waves coming from the southwest direction. The influence of tidal conditions on river mouth morphology is minimal. The tides are semi-diurnal with spring tides normally at $1.28 \mathrm{~m}$ and neap tides at $0.64 \mathrm{~m}$ [39]. The tidal range for this area is $1 \mathrm{~m}$ which makes it a micro-tidal environment. 

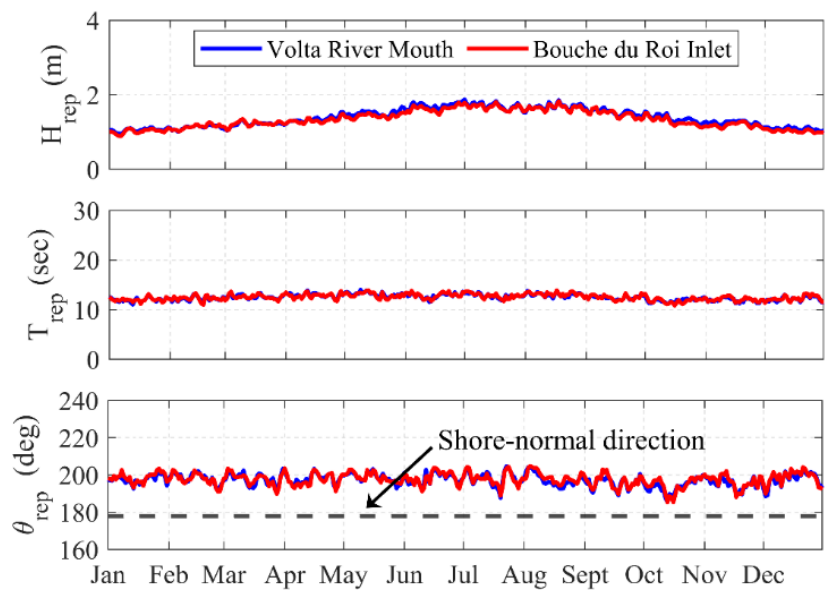

Figure 4. Wave energies for the Volta River mouth and Bouche du Roi inlet obtained from the WaveWatch III model (2005-2019).

\subsubsection{The "Bouche du Roi" Inlet, Benin}

The Bouche du Roi inlet is located along the southwestern stretch of the Benin coast (Figure 5a). It is the main outlet for the Mono River and Lake Aheme into the Gulf of Guinea. The Mono River has a catchment area of about $30,000 \mathrm{~km}^{3}$ and a total river network of about $400 \mathrm{~km}$. The inlet is located $140 \mathrm{~km}$ downdrift of the Volta River mouth. Unlike the restricted updrift sandspit at the Volta River mouth (after 2012), both sandspits at the Bouche du Roi inlet remain unrestricted (Figure 5b). However, the severe coastal erosion and seasonal coastal flooding remain a major issue between these two study areas. The Mono River forms part of the southern border between Togo and Benin with its management shared between the two countries. The area of Lake Aheme varies seasonally between $80 \mathrm{~km}^{2}$ in the dry season and $120 \mathrm{~km}^{2}$ in the rainy season [40].
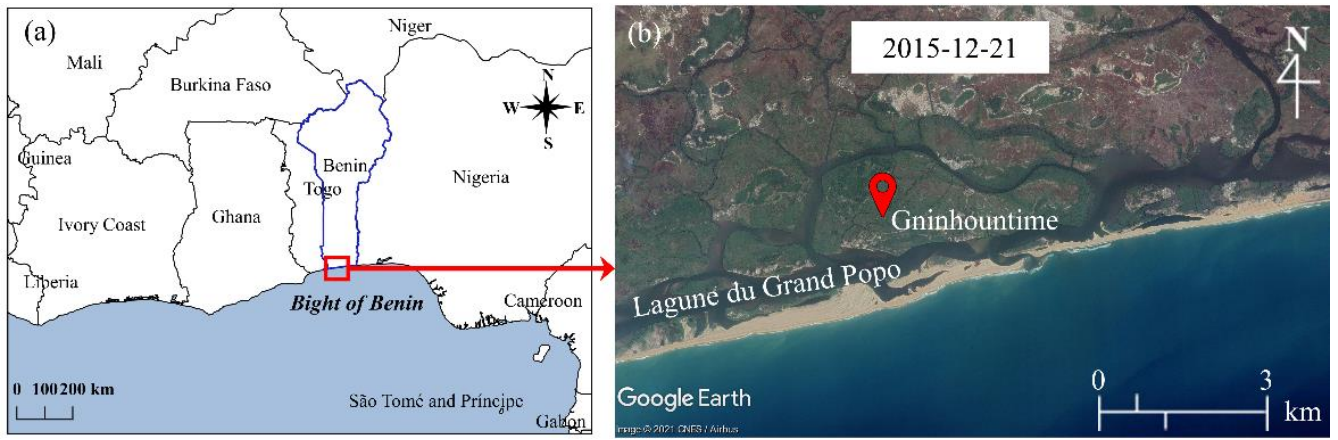

Figure 5. (a) Location of the Bouche du Roi inlet in Benin along the Bight of Benin coast. (b) The unrestricted sandspits at the inlet.

In the upstream section of the Mono River is the Nangbeto hydro-electric dam located about $135 \mathrm{~km}$ from the inlet. River discharge datasets were also collected from the GRDC from 1944 to 2007 and measured at the Athieme Gauge Station (located $74 \mathrm{~km}$ upstream of the inlet). As shown in Figure 6a, the pre-dam construction period was characterized by frequent mean monthly discharges of over $200 \mathrm{~m}^{3} / \mathrm{s}$, but this significantly reduced after dam construction. A 25-year numerical simulation (1987-2012) by Rossi et al. [41] predicted an estimated reduction in the annual river sediment supply to the inlet from 100,000 to $25,000 \mathrm{~m}^{3}$ /year after construction of the Nangbeto dam. 

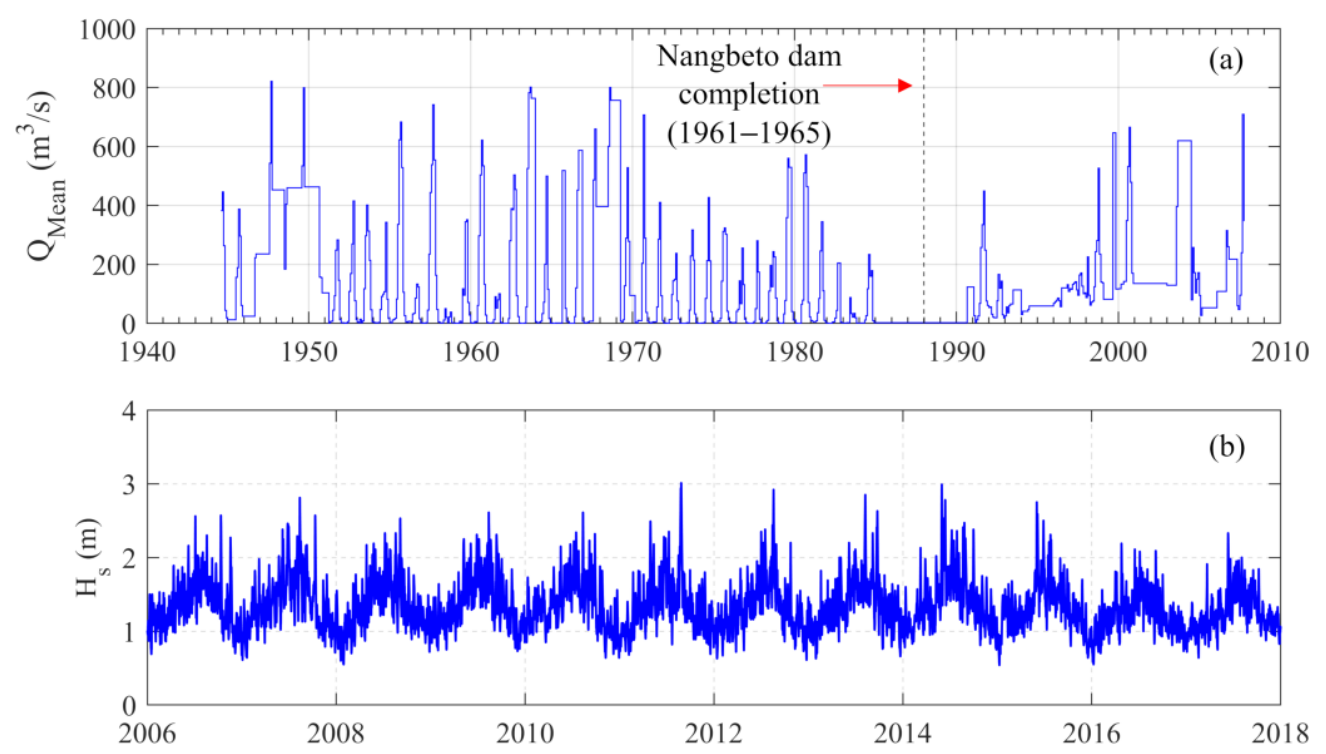

Figure 6. (a) Monthly averaged river discharge at the Athieme Station (1944-2007). (b) Significant wave heights for the Bouche du Roi inlet collected from the WaveWatch III model (2005-2017).

The yearly wave conditions at the Bouche du Roi inlet are almost identical to those of the Volta River mouth (Figure 4). Offshore wave information was collected from the WaveWatch III model at an offshore distance of $35 \mathrm{~km}$ from the inlet from 2005 to 2017 (Figure 6b). A slight difference between the two study areas in terms of wave incidence on the shoreline is the shore-normal direction with an angle of about $178^{\circ}$. The wave incidence on the estuary varies between $10^{\circ}$ and $15^{\circ}$ with waves approaching from the southwest direction. Tidal conditions are also identical to those impinging the Volta River mouth, with neap tides usually at $0.68 \mathrm{~m}$ and spring tides at $1.32 \mathrm{~m}$ [39].

\subsection{Satellite Image Analysis and Shoreline Detection}

\subsubsection{Landsat and Sentinel-2 Image Processing}

The main sets of images used in the analysis were the Landsat satellite collections, i.e., Landsat 5 (TM), Landsat 7 (EMT+) and Landsat 8 (OLI), and Sentinel-2 (MSI). Image acquisition, processing and shoreline detection were performed using the Coastsat toolkit developed by [42]. The Coastsat toolkit is an open-source toolkit with the capability of retrieving historic satellite images from the Google Earth Engine (GEE). Acquired images are then taken through a pre-processing stage that involves cloud masking, pan sharpening and downsampling. This process enables a spatial enhancement of the satellite images. The spatial enhancement results in a downsampled resolution from 30 to $15 \mathrm{~m} /$ pixel for the Landsat images and from 20 to $10 \mathrm{~m} /$ pixel for the Sentinel-2 images. The shorelines are then extracted using the modified normalized water index (MNDWI) expressed as follows:

$$
M N D W I=\frac{S W I R 1-G}{S W I R 1+G}
$$

where SWIR1 is the short-wave infrared band, and $G$ is the green band. The shoreline detection techniques in the Coastsat toolkit result in the extraction of shorelines with a horizontal accuracy of $10 \mathrm{~m}$. Further details on the techniques employed in the Coastsat toolkit can be found in [42,43]. Information on the number of images acquired for the two study areas is presented in Table 1 below. 
Table 1. Information on retrieved Landsat (5, 7 and 8) and Sentinel-2 images for the study areas.

\begin{tabular}{ccc}
\hline Satellite Missions & Volta River Mouth & Bouche du Roi Inlet \\
\hline Landsat $5(\mathrm{TM})$ & 7 & 14 \\
Landsat 7 (EMT+) & 17 & 20 \\
Landsat 8 (OLI) & 26 & 79 \\
Sentinel-2 (MSI) & 80 & 163 \\
\hline
\end{tabular}

In the two study areas analyzed, a no-data gap was present from 1993 to 1997 for the Landsat satellite collections. In that regard, morphodynamic conditions within this period are not discussed in this paper. Furthermore, the Landsat satellite images acquired between 2004 and 2012 were characterized by radiometric error (line drop-out), and therefore the need to use other image sources arose. Corrections for the radiometric error on the Landsat images are available in the Google Earth Pro software. These images were used as an alternative source within this period.

\subsubsection{Google Earth Image Processing}

The radiometrically corrected satellite and aerial images in the Google Earth Pro software served as the supplementary image source for the Landsat and Sentinel-2 satellite images. A total of 34 images were retrieved for the Volta River mouth, and 33 images were retrieved for the Bouche du Roi inlet. Retrieved images were rectified into a single coordinate system (WGS-84/UTM Zone 31N). The image rectification process required the selection of sufficient and accurate ground control points (GCPs). Collected images were rectified using these GCPs in an affine transformation. Subsequently, the shorelines were detected based on the contrast between the wet and dry sand pixels.

\subsection{Sandspit Growth and Longshore Sediment Transport Estimation Model}

In this study, a simple analytical model was utilized to estimate the longshore sediment transport rates (LSTRs). This model was formulated on the sand volume conservation and the development process of unrestricted sandspits located at river mouths or tidal inlets. The early works of Tanaka et al. [44] and Kraus [45] form the basis of this model. In a comprehensive study by Duc Anh et al. [37] for the Central Coast of Vietnam, in which this model and the Delft3D numerical model were applied, the magnitudes of the estimated LSTRs were in the same order which makes the simple analytical method suitable for this study. Furthermore, measurements of impounded longshore sediment transport at jetties, breakwaters and sandspits have been reported to yield estimates close to the total sediment transport quantities (i.e., bed load and suspended load transport) [46].

The analytical model assumes that gradients in longshore sediment transport $\left(Q_{x}\right)$ directly feed the elongation of the sandspit. In addition, the sandspit has a constant width $\left(B_{S}\right)$ during its growth, and active movement of the sandspit is confined within the vertical distance known as the depth of active sediment motion for a specific period $(t)$. The depth of active sediment motion $(D)$ is given as the sum of the depth of closure $\left(D_{C}\right)$ and berm elevation $\left(D_{B}\right)$. Details on the depth of closure and berm elevation estimation methods are provided in Section 2.4. A schematic diagram of the model is presented in Figure 7 below. 


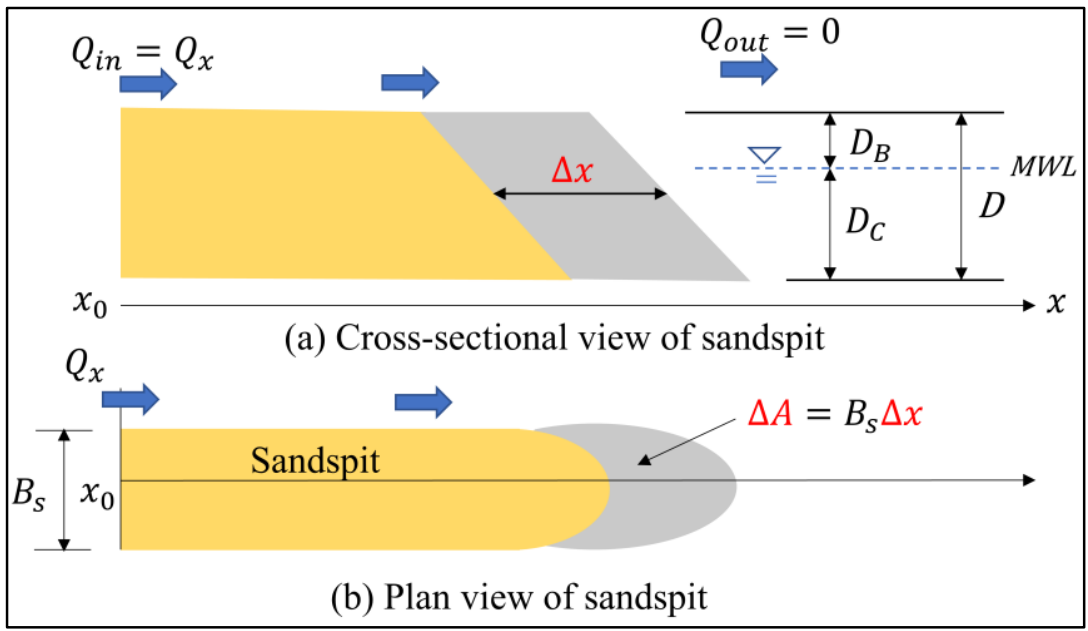

Figure 7. Schematic diagram for the sandspit development process: (a) cross-sectional view of the sandspit, and the definition of the berm elevation and depth of closure with respect to the mean water level (MWL); (b) Plan view of the sandspit.

Based on the assumptions imposed in the model, the volumetric change rate of the sandspit is equivalent to the amount of sediment directly sustaining the growth of the sandspit $\left(Q_{i n}\right)$ within a specific period $(\Delta t)$. Sediment bypassing $\left(Q_{\text {out }}\right)$ at the river mouth or tidal inlet is assumed to be zero. Hence, the LSTR $\left(Q_{x}\right)$ is given as follows:

$$
Q_{i n}=Q_{x}=D \times \frac{\Delta A}{\Delta t}
$$

where $D$ is the depth of active sediment motion, and $\Delta A$ is the sandspit area changes within a specific period $(\Delta t)$.

\subsection{Estimation of Depth of Closure and Berm Elevation}

In the model applied in this study, the depth of closure and berm elevation are two valuable parameters required for the estimation of the longshore sediment transport rates. The depth of closure is an important morphological parameter used in defining the seaward limit of significant changes in the beach profile. Hallermeier $[47,48]$ successfully defined this depth using both laboratory and field data. Wave data spanning over a decadal or yearly time scale is required to define the depth of closure when using the Hallermeier equation which is expressed as:

$$
D_{C}=2.28 H_{S}-68.5\left(\frac{H_{S}^{2}}{g T_{S}^{2}}\right)
$$

where $H_{S}$ is the effective significant wave height with an exceedance probability of $0.137 \%$ per year, $T_{S}$ is the associated wave period and $g$ is the acceleration due to gravity. The limitations of applying Equation (3) have been discussed in studies by Udo et al. [49] and Razak and Khan [50]. These limitations were identified by comparing results for field surveys of wave conditions and wave data obtained from hindcast wave models. Based on these limitations, we applied a $\pm 20 \%$ error margin to our depth of closure calculations which is reflected in the cumulative error of our estimates (Section 4.1).

Regarding the berm elevation, Uda [51] derived an empirical equation that relates the depth of closure to the berm elevation. This relationship was established using measured data in Japan and is expressed as:

$$
D_{B}=0.32 \times D_{C}
$$


In the absence of field measurements, this relationship can prove useful in obtaining an approximate value for the berm elevation. Table 2 lists the depth of closure and berm elevation values for the Bouche du Roi inlet using offshore wave data from the WaveWatch III model. Additionally, the depth of closure calculated by Roest [52] using nearshore wave data and the Hallermeier equation for the coastal system of the Volta Delta is provided in Table 2. For analysis involving the Volta River mouth, the depth of closure calculated by Roest [52] was used since nearshore wave information accounts for wave shoaling effects on the beach profile morphology.

Table 2. Estimated depth of closure and berm elevation for the study areas.

\begin{tabular}{ccc}
\hline Study Area & Depth of Closure, $D_{C}(\mathbf{m})$ & Berm Elevation, $D_{B}(\mathbf{m})$ \\
\hline Volta River mouth [52] & 7.40 & 2.4 \\
Bouche du Roi inlet & 6.03 & 1.92 \\
\hline
\end{tabular}

\section{Results}

\subsection{The Case of the Volta River Mouth, Ghana}

\subsubsection{Morphological Timelines}

The sandspits at the Volta River mouth are directly shaped by both anthropogenic and natural processes in its morphological evolution. To have a clear understanding of how these processes affect the development of the sandspits, we divided the study period into three distinct morphological timelines (Figure 8). The first and second periods are referred to as the pre-ASDP period, and the third period as the post-ASDP period. In the first period (1984-1999), rapid elongation of the updrift sandspit is observed from the west to east direction (Figure 8b). This direction of sandspit growth is analogous to the direction of longshore sediment transport along the Bight of Benin coast. The constant elongation of the updrift sandspit results in the subsequent migration and narrowing of the river mouth. Before stabilization of the updrift sandspit by the ASDP, regular artificial breaching of the sandspits was undertaken (Figure 8c,f,g). The breaches in these figures are indicated by green-outlined circles for the updrift sandspit breaching and red-outlined circles for the downdrift sandspit breaching. These breaches, i.e., VB-01, VB-02 and VB-03, were aimed at reducing flooding events and increasing salinity levels in the estuary to eradicate the intermediary hosts of schistosomiasis [53].

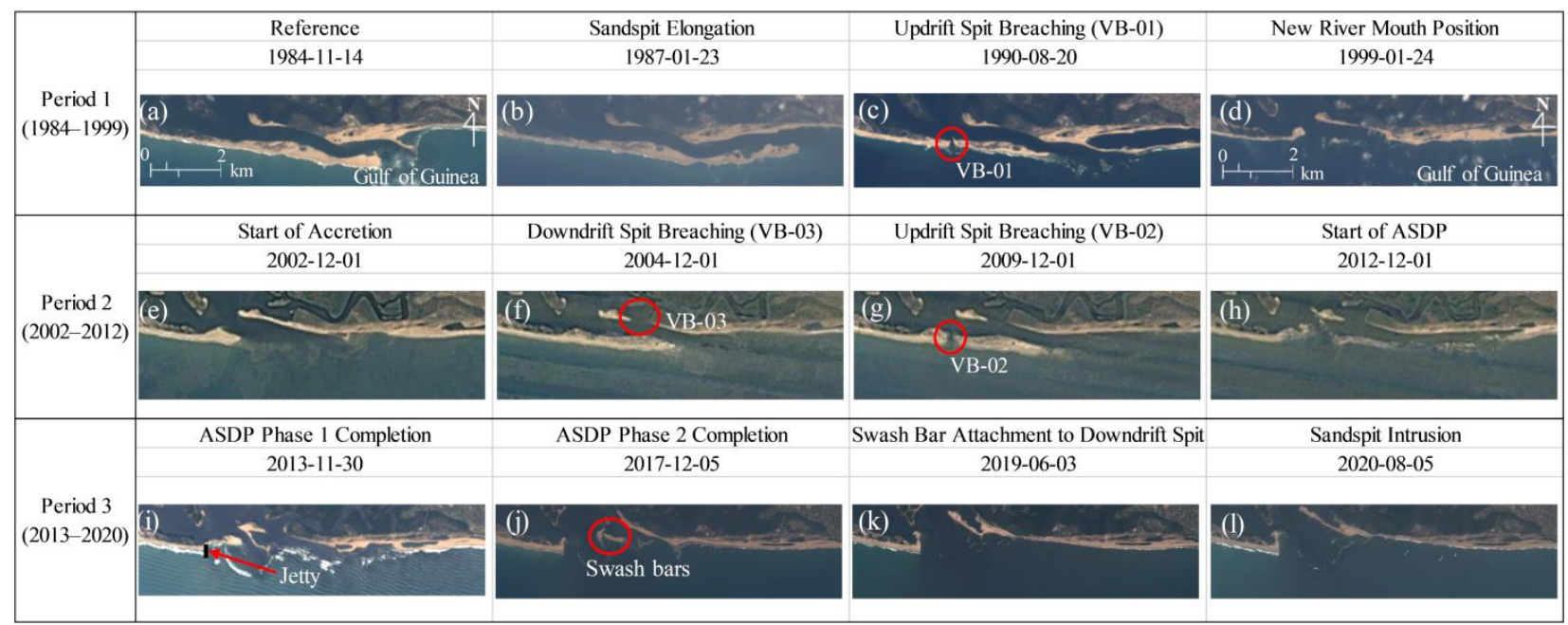

Figure 8. (a-1) Retrieved satellite images highlighting the three morphological timelines designated for the Volta River mouth from November 1984 to May 2020. 
In the second period (2002-2012), similar morphological trends to those of the first period were observed. In Figure 8e, accretion of longshore sediment transport by the updrift sandspit begins after the breached portion of the spit is completely washed away in the downdrift direction. The post-ASDP period (2013-2020) is denoted by morphological trends completely different to those of the first and second periods. This period depicts the river mouth's response to the ASDP and is a useful indicator of the cascading effects of engineering activities on natural coastal processes. A notable response of the river mouth is the intrusion of both the updrift and downdrift sandspits into the estuary. In the case of the updrift sandspit, the intrusion could be attributed to sediment bypassing the jetty which is then deposited on the unrestricted tip of the spit via wave breaking (Figure 8k). This has manifested in the "drumstick" shape of the intruded updrift sandspit. With respect to the downdrift sandspit, intrusion is advanced by the attachment of swash bars formed in the ebb delta (Figure 8j). The swash bars are formed under the influence of wave action. Subsequently, high wave energies at the river mouth lead to the landward migration of the swash bars and attachment to the downdrift sandspit. Further assessment of sandspit intrusion and its knock-on effects is provided in Section 3.1.4.

\subsubsection{Sandspit Growth Rates}

After detection of the river mouth shorelines from the acquired satellite images, we schematically defined sandspit parameters relevant to our analysis. As detailed in Figure 9a, we defined the alongshore coordinates of the updrift and downdrift sandspits as $x_{V 1}$ and $x_{V 2}$, respectively. The definition of the alongshore sandspit coordinates shows the sandspit tip position when each satellite image was captured. In our analysis, we focused solely on the updrift accreting sandspit in terms of sandspit growth rates and areal changes. By plotting a time variation of the updrift sandspit $x_{V 1}$ tip positions, the long-term variability of the sandspit can be depicted (Figure 9b). Even though the Landsat, Sentinel-2 and Google Earth images were of different resolutions, we see a close agreement between these image sources in the time variation plots.
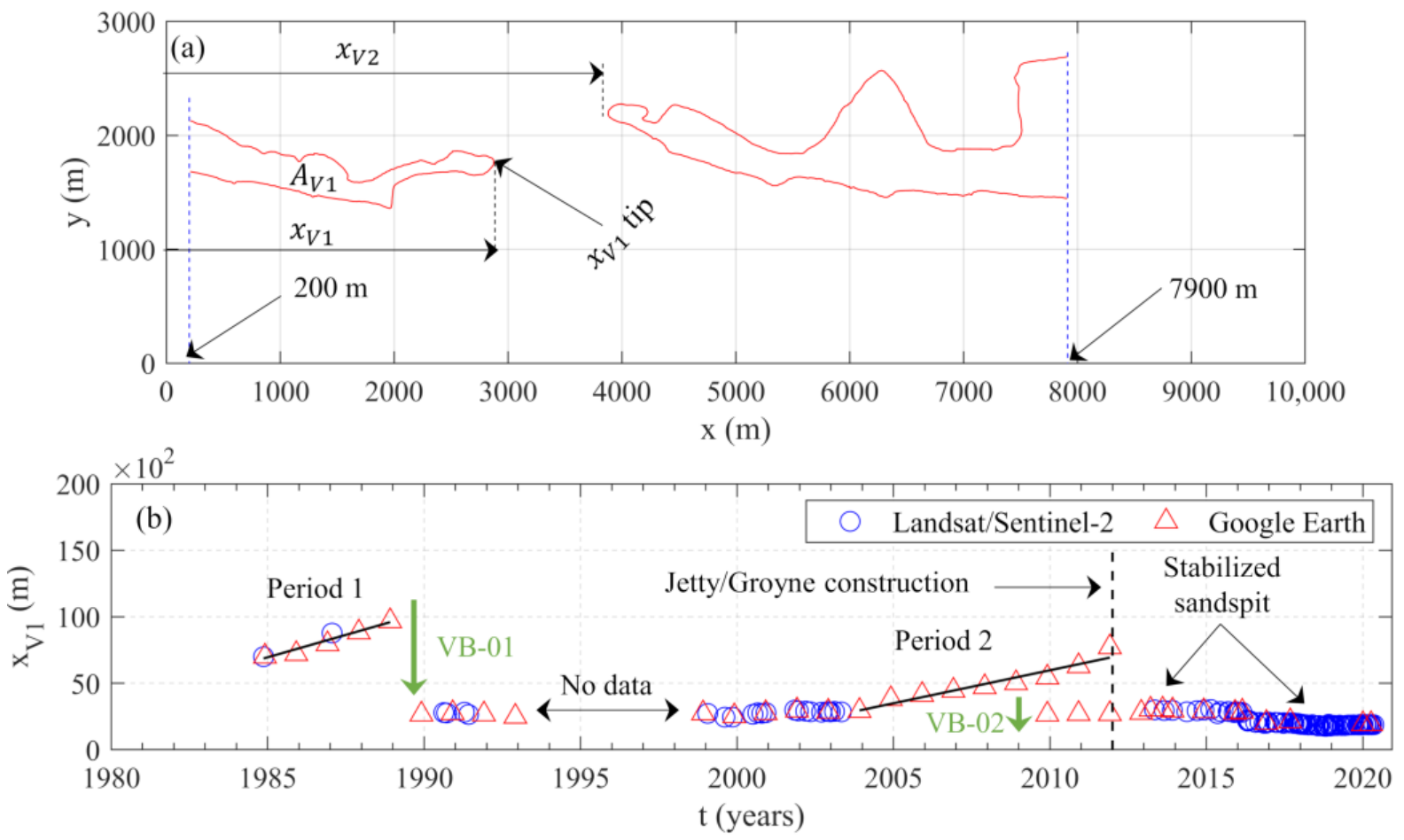

Figure 9. (a) Definition of sandspit coordinate system for the Volta River mouth. (b) Time variation of the sandspit alongshore $x_{V 1}$ tip positions for the Volta River mouth (1984-2020). 
From Figure 9b, linear regression can be applied to Periods 1 and 2 to obtain the sandspit growth rates. The regression analysis yielded Equations (5) and (6) for Period 1 and Period 2, respectively, which are given as follows:

For Period 1:

$$
\Delta x_{V 1}=674.06 \times(t-1984)+6276
$$

For Period 2:

$$
\Delta x_{V 1}=495.79 \times(t-2003)+2505
$$

where $\Delta x_{V 1}$ is the updrift sandspit growth rate (m/year) and $t$ is the time (year).

As shown in Figure 9b, the updrift sandspit constantly elongates in Period 1 until it reaches a maximum length of $9672 \mathrm{~m}$ when it was artificially breached in 1990. Using Equation (5) for Period 1, a growth rate of $674 \mathrm{~m} /$ year was estimated for this period. In the second period, updrift sandspit elongation trends that are identical to the first period were observed. However, the maximum length before breaching of the sandspit was at approximately $5438 \mathrm{~m}$ in 2009. The non-growth of the sandspit between 1991 and 2003 was due to the breached portion of the sandspit inhibiting the growth of the spit which is attached to the headland. Sediment from the breached spit was gradually deposited onto the downdrift beach (Figure 8c,d). Additionally, the sandspit was manually breached in 1996 as reported by [53]. In contrast, the overlap of $x_{V 1}$ tip positions between 2009 and 2011 in Figure $9 \mathrm{~b}$ is due to accretion of longshore sediment by the breached portion of the spit after the breaching event (VB-02). From Equation (6), the growth rate for the second period was estimated at $496 \mathrm{~m}$ /year. In the third period, it is observed that the $x_{V 1}$ tip position becomes constant after 2012 due to stabilization by the ASDP.

\subsubsection{Longshore Sediment Transport Rates}

As discussed in Section 2.3, the LSTR for a specific period is evaluated as the product of the depth of active sediment motion and the sandspit area change rate during that period. For the Volta River mouth, the updrift sandspit area is defined as $A_{V 1}$ (Figure 9b). Figure 10 shows the time variation of the updrift sandspit area from 1984 to 2020.

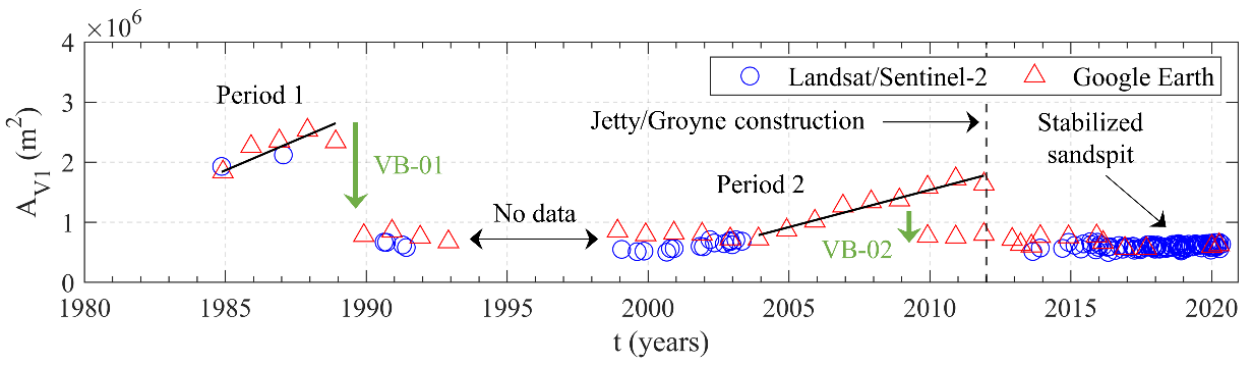

Figure 10. Time variations of the sandspit area changes $\left(A_{V 1}\right)$ for the Volta River mouth (1984-2020).

After performing regression analysis for Period 1 and Period 2, the estimated sandspit area change rates were $1.32 \times 10^{5} \mathrm{~m}^{2} /$ year and $1.24 \times 10^{5} \mathrm{~m}^{2} /$ year, respectively. These rates were obtained using Equations (7) and (8) for Period 1 and Period 2, respectively, which are given by

For Period 1:

$$
\Delta A_{V 1}=131,885 \times(t-1984)+2.0 \times 10^{6}
$$

For Period 2:

$$
\Delta A_{V 1}=123,869 \times(t-2003)+6.7 \times 10^{5}
$$

where $\Delta A_{V 1}$ is the updrift sandspit area change rate $\left(\mathrm{m}^{2} /\right.$ year) and $t$ is the time (year).

Using the depth of active sediment motion value in Table 2 for the Volta River mouth, i.e., $D=9.8 \mathrm{~m}$, the LSTR for Period 1 and Period 2 yields an estimate of $1.29 \times 10^{6} \mathrm{~m}^{3} /$ year and $1.21 \times 10^{6} \mathrm{~m}^{3} /$ year, respectively. Hence, the average longshore sediment transport rate at the Volta River mouth is at about $1.25 \times 10^{6} \mathrm{~m}^{3} /$ year. 


\subsubsection{Impact of the ASDP on Sandspit Evolution}

The response of a river mouth sandspit to alterations induced by jetty construction or other natural events such as tsunamis varies based on the local hydrodynamic and topographic conditions. As reported in studies by Hiep et al. [54] and Tanaka and Lee [55], notable changes in the river mouth morphology can be observed after major alterations in the vicinity of a river mouth. Sediment deposition and a decrease in wave setup in the river mouth were some reported observations. For this reason, we assessed the impact of the jetty and groyne system on the morphology of the Volta River mouth to highlight its localized response to the ASDP. The project was recognized as a viable solution to the numerous coastal problems at the Volta River mouth. Figure 11 shows a plot of the river mouth shorelines after construction of the jetty and groyne system (Period 3). Examining the shorelines of the western side of the river mouth revealed beach advancement as expected. In contrast, severe erosion along the eastern side of the river mouth was observed due to the deficit in the sediment balance at the river mouth initiated by the accreting groyne system.

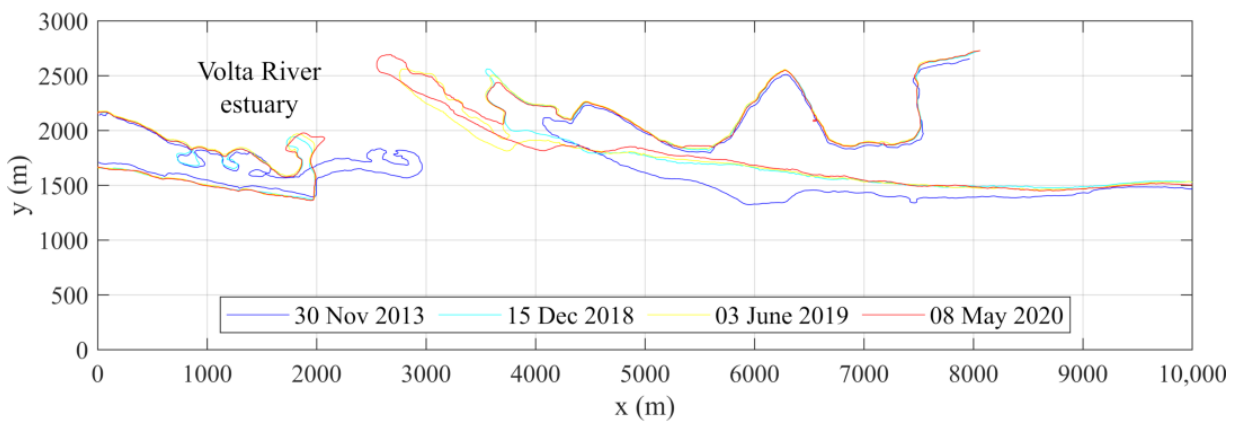

Figure 11. Volta River mouth shorelines after completion of the ASDP (2013-2020).

From Figure 11, it is observed that the updrift and downdrift sandspits intrude into the estuary in the post-ASDP period (2013-2020). This is a typical scenario where changes to the coastal environment through engineering works result in unforeseen or unintended alterations. Figure 12a,b show the time variation of the corresponding updrift $x_{V 1}$ tip ycoordinate $\left(y_{V 1}\right)$ and the corresponding downdrift $x_{V 2}$ tip y-coordinate $\left(y_{V 2}\right)$, respectively. These coordinates were used to evaluate the sandspit intrusion rates into the estuary. From our analysis, the updrift sandspit intrudes into the estuary at a rate of $60 \mathrm{~m} /$ year, whereas the downdrift sandspit intrudes at a rate of $80 \mathrm{~m} /$ year. An implication of sandspit intrusion is the narrowing of the river mouth width (Figure 12c).

\subsection{The Case of the Bouche du Roi Inlet, Benin}

\subsubsection{Morphological Timelines}

Considering the Bouche du Roi inlet, we categorized the morphological timelines into four different periods (Figure 13). Here, we differentiated the timelines based on sandspit elongation and breaching events. The inlet positions in Figure 13 are indicated by the whitefilled arrows to highlight the constant migration of the inlet, whereas breaches are indicated by white-filled and red-outlined arrows. On the other hand, breaching of the downdrift sandspit is marked by a red-outlined circle. In the first period (1984-1991), eastward elongation of the updrift sandspit is observed (Figure 13a,b). The eastward growth of the updrift sandspit results in the retreat of the downdrift sandspit or the complete closure of the inlet. The downdrift sandspit retreats owing to the longshore sediment accumulation by the updrift sandspit which causes the downdrift sandspit to erode under the influence of the prevailing wave and river discharge conditions. Within the first period, the inlet experienced a closure in 1987, as shown in Figure 13c. Upon closure, a new opening of the inlet was created. However, it is unclear whether the mechanism of sandspit breaching within this period was natural or artificial due to the limited information from the previous records and literature. The breach within this period is denoted as BB-01. Furthermore, 
the first period in this study area represents the period within which the Nangbeto dam was constructed (1984-1986). Hence, the subsequent analysis for the Bouche du Roi inlet was aimed at evaluating the morphodynamic changes in the estuary before and after dam construction. The post-dam construction periods, i.e., Period 2 (1998-2008), Period 3 (2009-2016) and Period 4 (2016-2020), are periods in which the estuarine morphological evolutions greatly differ from the first period. Within the post-dam construction periods, rapid elongation of the updrift sandspit is a common morphological phenomenon observed at the inlet (Figure 13e,h,n). Similar to the first period, the effect of rapid updrift sandspit elongation is the near or complete closure of the inlet (Figure 13h,l,n). This condition necessitates the breaching of the sandspits to ensure an efficient tidal exchange between the lagoon and the ocean. It also ensures the prevention of coastal flooding in the surrounding communities. Manual breaching campaigns such as those conducted in 1999 (Figure 13f) and 2009 (Figure 13i) are examples of some coastal management programs executed at the Bouche du Roi inlet to ensure the substantiality of the tidal inlet.
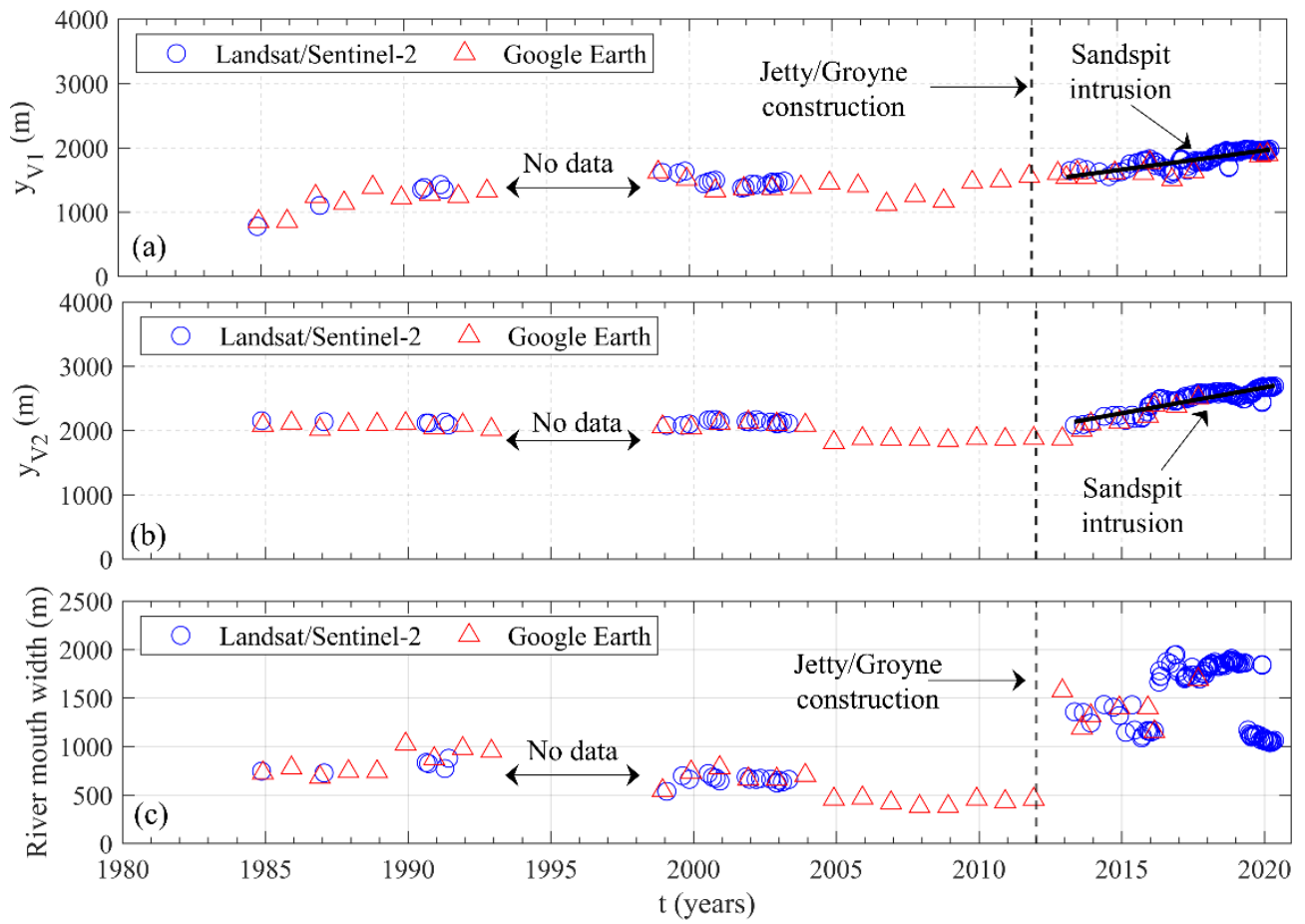

Figure 12. Time variation of sandspit y-coordinates to depict sandspit intrusion into the Volta River estuary in the post-ASDP period: (a) updrift sandspit $y_{V 1}$ time variation; (b) downdrift sandspit $y_{V 2}$ time variation; (c) variation in the river mouth width.

\subsubsection{Sandspit Growth Rates}

To quantify the sandspit growth rates, a similar approach was used as in the case of the Volta River mouth in Section 3.1.2. Figure 14a shows the definition of the coordinate system created for the Bouche du Roi inlet. Here, the alongshore coordinate of the updrift sandspit tip is defined as $x_{B 1}$. The time variation of the $x_{B 1}$ tip positions from 1984 to 2020 is presented in Figure 14b. In the sandspit growth rate analysis, Period 3 (2009-2016) was excluded from the analysis due to the varying spit width during the development of the sandspit. In the sandspit growth and LSTR model described in Section 2.3, it is assumed that the sandspit maintains a constant width during the growth process. The attachment of a breached portion of the downdrift sandspit to the updrift sandspit in its development process is one of the factors responsible for the varying updrift sandspit within this period. Therefore, the results for the Bouche du Roi inlet in this section and Section 3.2.3 exclude the analysis for Period 3 (2009-2019). 


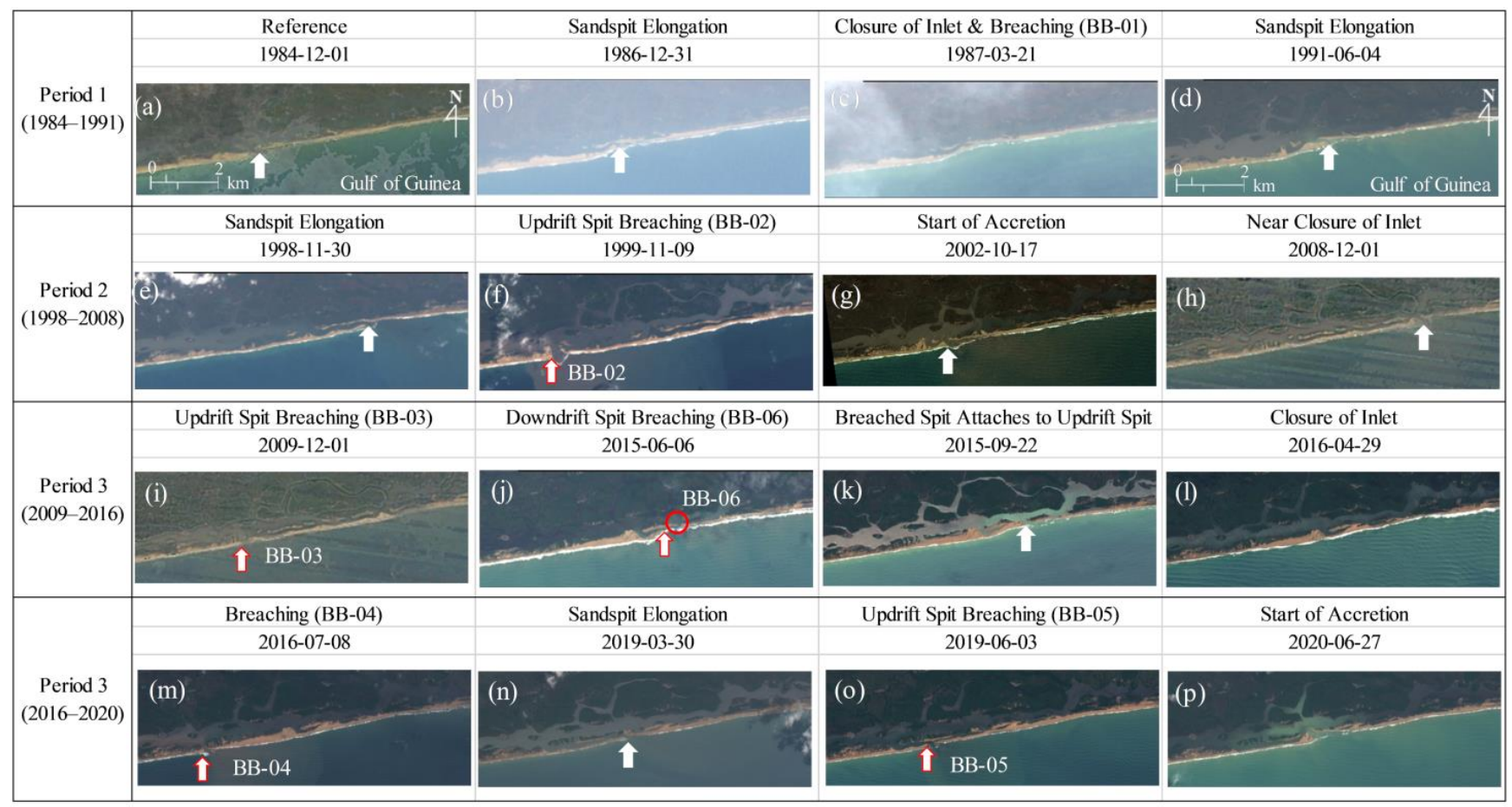

Figure 13. (a-p) Retrieved satellite images highlighting the four morphological timelines designated for the Bouche du Roi inlet from December 1984 to June 2020.
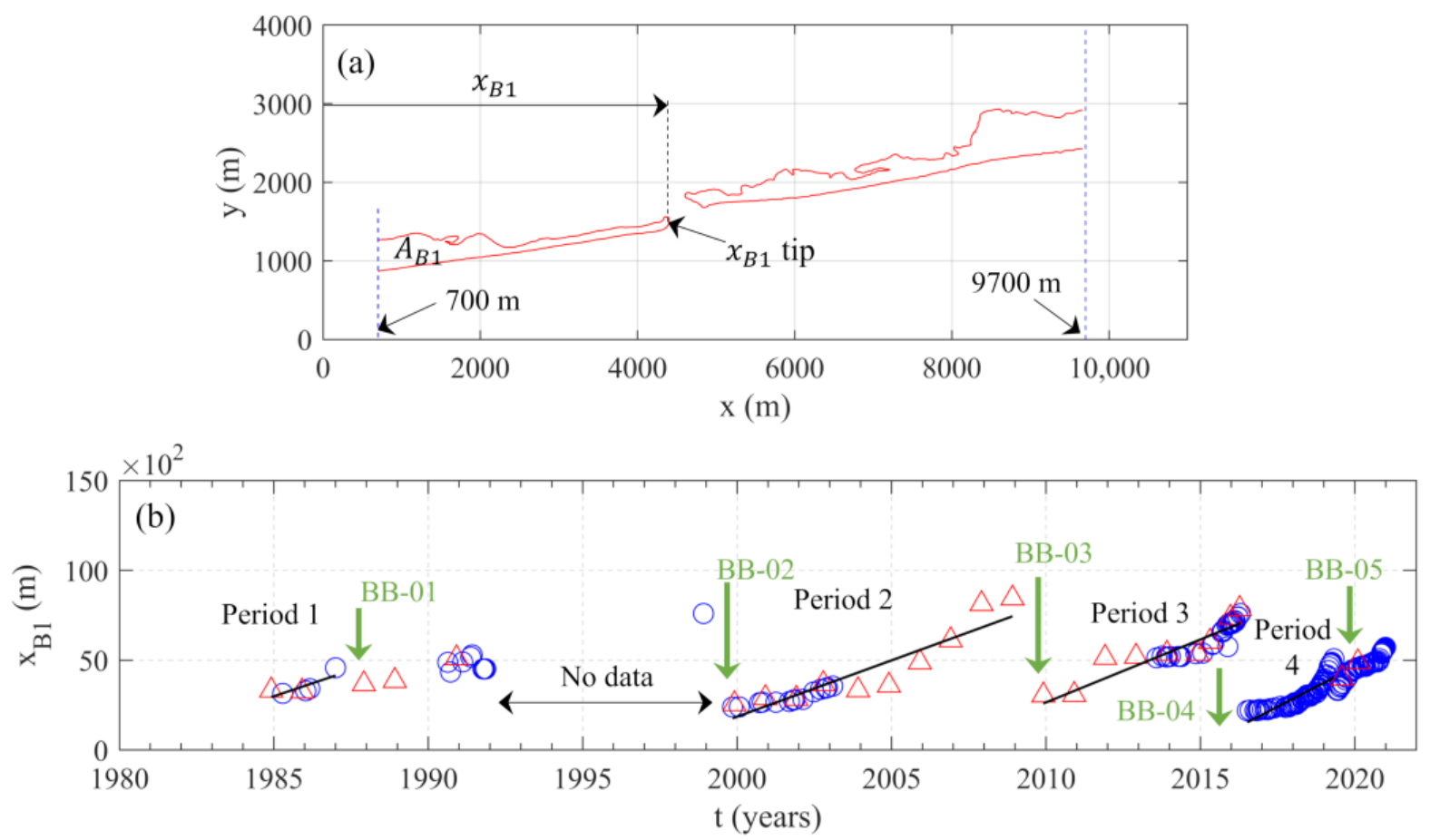

Figure 14. (a) Definition of sandspit coordinate system for the Bouche du Roi inlet. (b) Time variation of the sandspit alongshore $x_{B 1}$ tip positions for the Bouche du Roi inlet (1984-2020).

From Figure 14b, linear regression equations can be obtained for the respective periods to obtain the sandspit growth rates. The regression equations for Period 1, Period 2 and Period 4 are given as follows:

For Period 1:

$$
\Delta x_{B 1}=577.82 \times(t-1984)+2414
$$


For Period 2:

$$
\Delta x_{B 1}=625.88 \times(t-1999)+1232
$$

For Period 4:

$$
\Delta x_{B 1}=888.49 \times(t-2016)+1078
$$

where $\Delta x_{B 1}$ is the updrift sandspit growth rate ( $\mathrm{m} /$ year) and $t$ is the time (year).

In Period 1, the sandspit growth rate was estimated at the time when the Nangbeto dam was being constructed (1984-1986). The sandspit attained a maximum length of about $4579 \mathrm{~m}$ before it was breached in 1987 (Figure 14b). During this period, the growth rate of the sandspit was estimated at about $578 \mathrm{~m} /$ year. With regard to Period 2 (1998-2009), the sandspit reached a maximum length of $8440 \mathrm{~m}$ before the sandspit was artificially breached. A growth rate of about $626 \mathrm{~m} /$ year was evaluated for this period. Lastly, the fourth period (2016-2019) revealed an updrift sandspit maximum length of $5083 \mathrm{~m}$ and a growth rate of about $889 \mathrm{~m} /$ year.

\subsubsection{Longshore Sediment Transport Rates}

Estimation of the LSTR follows the same procedure utilized in Section 3.1.3. For the Bouche du Roi inlet, we defined the updrift sandspit area as $A_{B 1}$ (Figure 14a). The updrift sandspit areas were calculated, and the time variation of the area changes is presented in Figure 15.

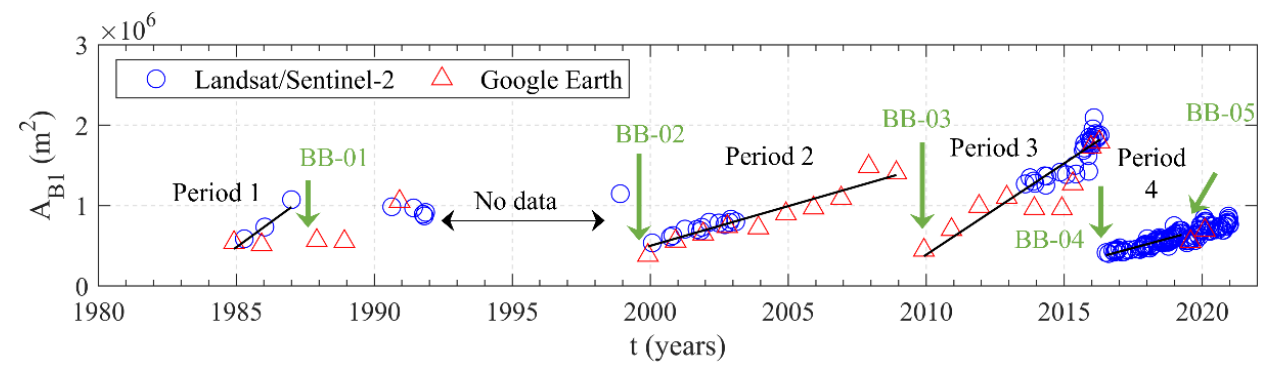

Figure 15. Time variation of the updrift sandspit area changes $\left(A_{B 1}\right)$ for the Bouche du Roi inlet (1984-2020).

Regression analysis of the updrift sandspit areas for the various periods in Figure 15 resulted in the following equations:

For Period 1:

$$
\Delta A_{B 1}=249,909 \times(t-1984)+2.32 \times 10^{5}
$$

For Period 2:

$$
\Delta A_{B 1}=98,579 \times(t-1999)+4.02 \times 10^{5}
$$

For Period 4:

$$
\Delta A_{B 1}=92,676 \times(t-2016)+3.35 \times 10^{5}
$$

where $\Delta A_{B 1}$ is the updrift sandspit area change rate $\left(\mathrm{m}^{2} /\right.$ year) and $t$ is the time (year).

From the equations presented above, the estimated sandspit area change rates for Period 1 (1984-1986), Period 2 (1998-2009) and Period 4 (2016-2019) were $2.50 \times 10^{5} \mathrm{~m}^{2} /$ year, $9.86 \times 10^{4} \mathrm{~m}^{2} /$ year and $9.30 \times 10^{4} \mathrm{~m}^{2} /$ year, respectively. Using the depth of active sediment motion value $(D=7.95 \mathrm{~m})$, as provided in Table 2 , and the sandspit area change rate for each period, the LSTR for the Bouche du Roi inlet was determined. The estimated LSTRs for Period 1 (1984-1986), Period 2 (1998-2009) and Period 4 (2016-2019) were $1.98 \times 10^{6} \mathrm{~m}^{3} /$ year, $7.81 \times 10^{5} \mathrm{~m}^{3} /$ year and $7.34 \times 10^{5} \mathrm{~m}^{3} /$ year, respectively. This returned an average LSTR of about $1.20 \times 10^{6} \mathrm{~m}^{3}$ /year estimated from the sandspit development at the Bouche du Roi inlet. 


\subsection{Relationship between Sandpsit Growth Rates and Spit Width}

In this section, we adopted a simple equation proposed by [37] to predict the sandspit growth rates as a function of the LSTR and sandspit width. The equation is centered on the sand volume conservation equation and assumes that for an unrestricted sandspit, its growth rate is inversely proportional to the width of the sandspit. In addition, the theory assumes a constant sandspit width during the elongation process. This is similar to the assumptions imposed in the LSTR model applied in this study. Hence, the sandspit growth rate is given as

$$
R_{S}=\frac{Q_{x}}{\left(D_{B}+D_{C}\right)} \frac{1}{B_{S}}=\alpha \frac{1}{B_{S}}
$$

where $R_{S}$ is the sandspit growth rate (m/year), $B_{S}$ is the sandspit width $(\mathrm{m})$ and $\alpha$ is the change rate coefficient ( $\mathrm{m}^{2} /$ year). The relationship between the sandspit growth rates and the spit width for the Volta River mouth and Bouche du Roi inlet is shown in Figure 16. The results for the Volta River mouth (Periods 1 and 2) are marked by the blue-filled circles and those of the Bouche du Roi inlet (Periods 1, 2 and 4) are represented by the green-filled circles.

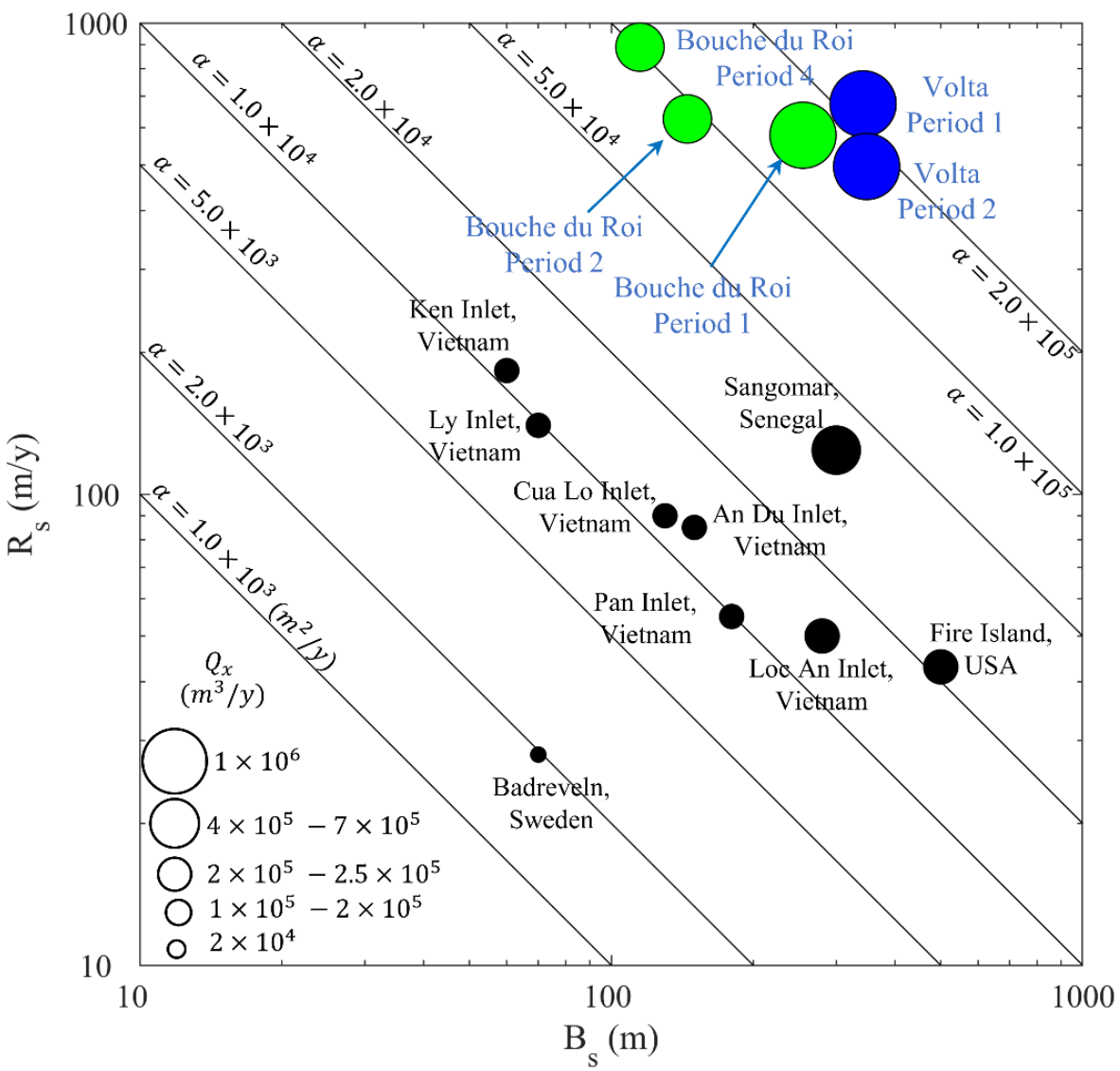

Figure 16. Relationship between sandspit growth rates and sandspit width for the current study and other estuaries.

Additionally, this figure presents the sandspit morphodynamic properties of other tidal inlets and river mouths in the world. These include sandspit characteristics for the Badreveln spit in Sweden and Fire Island Inlet investigated by [56], and the Sangomar in Senegal studied by [57]. In addition, six tidal inlets along the coast of Vietnam, namely, the Ken, Ly Hoa, Cua Loa, An Du, Phan and Loc An inlets, analyzed by [37,58-60], were also included in the plot. Table 3 summarizes the sandspit characteristics for the Volta River mouth, Bouche du Roi inlet and the other study areas considered in the sandspit growth rate and spit width relationship. 
Table 3. Summary of morphodynamic properties of study areas considered in the sandspit growth rate and sandspit width relationship.

\begin{tabular}{|c|c|c|c|c|}
\hline Study Area & Location & $R_{S}(\mathrm{~m} /$ year $)$ & $B_{S}(\mathrm{~m})$ & LSTR $\left(\mathrm{m}^{3} /\right.$ year $)$ \\
\hline $\begin{array}{l}\text { Volta River mouth } \\
\quad(\text { Period } 1)\end{array}$ & \multirow[b]{2}{*}{ Ghana } & 674 & 342 & $1.29 \times 10^{6}$ \\
\hline $\begin{array}{l}\text { Volta River mouth } \\
\text { (Period 2) }\end{array}$ & & 496 & 348 & $1.21 \times 10^{6}$ \\
\hline $\begin{array}{l}\text { Bouche du Roi inlet } \\
\text { (Period 1) }\end{array}$ & \multirow{3}{*}{ Benin } & 578 & 255 & $1.98 \times 10^{6}$ \\
\hline $\begin{array}{l}\text { Bouche du Roi inlet } \\
\text { (Period 2) }\end{array}$ & & 626 & 145 & $7.81 \times 10^{5}$ \\
\hline $\begin{array}{l}\text { Bouche du Roi inlet } \\
\text { (Period 4) }\end{array}$ & & 889 & 115 & $7.34 \times 10^{5}$ \\
\hline Badreveln spit & Sweden & 28 & 70 & $1.0 \times 10^{4}$ \\
\hline Fire Island Inlet & USA & 43 & 500 & $2.20 \times 10^{5}$ \\
\hline Sangomar spit & Senegal & 300 & 124 & $4.65 \times 10^{5}$ \\
\hline Ken inlet & \multirow{6}{*}{ Vietnam } & 55 & 180 & $1.33 \times 10^{5}$ \\
\hline Ly Hoa inlet & & 90 & 130 & $1.30 \times 10^{5}$ \\
\hline Cua Loa inlet & & 50 & 280 & $1.60 \times 10^{5}$ \\
\hline An Du inlet & & 140 & 70 & $1.70 \times 10^{5}$ \\
\hline Phan inlet & & 183 & 60 & $1.45 \times 10^{5}$ \\
\hline Loc An inlet & & 85 & 150 & $2.0 \times 10^{5}$ \\
\hline
\end{tabular}

From Figure 16, it is apparent that the results for Periods 2 and 4 (Bouche du Roi inlet) perfectly fit the $\alpha$ contour lines for the $R_{S}-B_{S}$ relationship. However, a contrast is observed for Periods 1 and 2 for the Volta River mouth and Period 1 for the Bouche du Roi inlet. Within these three periods, an LSTR of magnitude $10^{6} \mathrm{~m}^{3} /$ year was recorded. This provides an indication that the results from Equation (13) at tidal inlets or river mouths with LSTR magnitudes in the order of $10^{6} \mathrm{~m}^{3}$ /year may substantially vary from those measured through satellite images or actual measurements. Other morphodynamic parameters may account for this variation [61]. In Table 4, the differences between the sandspit growth rates from satellite images and those calculated using Equation (15) for the Volta River mouth and Bouche du Roi inlet are presented.

Table 4. Sandspit growth rates for the Volta River mouth and Bouche du Roi inlet from satellite measurements and predicted growth rates from Equation (15).

\begin{tabular}{ccc}
\hline Study Area & $\boldsymbol{R}_{S}$ (m/year) & $\boldsymbol{R}_{S}$ (m/year) \\
\cline { 2 - 3 } & (Satellite Images) & (Equation (15)) \\
\hline $\begin{array}{c}\text { Volta River mouth } \\
\text { (Period 1) } \\
\begin{array}{c}\text { Volta River mouth } \\
\text { (Period 2) }\end{array}\end{array}$ & 674 & 382 \\
$\begin{array}{c}\text { Bouche du Roi inlet } \\
\text { (Period 1) }\end{array}$ & 496 & 358 \\
$\begin{array}{c}\text { Bouche du Roi inlet } \\
\text { (Period 2) }\end{array}$ & 578 & 977 \\
$\begin{array}{c}\text { Bouche du Roi inlet } \\
\text { (Period 4) }\end{array}$ & 626 & 677 \\
\hline
\end{tabular}

\section{Discussion}

\subsection{LSTR Comparative Study}

The results from this study suggest that the LSTRs are in the order of $10^{5}-10^{6} \mathrm{~m}^{3} /$ year for the Bight of Benin coast (Figure 17). From Figure 17, we report an average error margin 
of $\pm 2.50 \times 10^{5} \mathrm{~m}^{3} /$ year in the LSTR estimates for this study. Nonetheless, our estimates are consistent with previous studies that used empirical formulas and measurement of sediment deposited at port breakwaters to estimate LSTRs for this coast. The LSTR range obtained from the approaches mentioned lies between $4 \times 10^{5}$ and $1 \times 10^{6} \mathrm{~m}^{3} /$ year for the Bight of Benin coast [62]. The estimated LSTRs in the current study are, without doubt, in close agreement with those obtained using different approaches. The high longshore sediment transport recorded in the Bight of Benin can be attributed to three distinct morphodynamic processes driving sediment transport along this coast. The first morphodynamic parameter steering the high magnitude of longshore sediment transport is the predominant river sediment supply from the Volta River. According to Amenuvor et al. [38], the fluvial sediment from the Volta River is in the order of $10^{6} \mathrm{~m}^{3} /$ year. The river sediment supplied via the Volta River mouth into the downdrift coast is reworked by the prevailing wave conditions. The wave climate along this coast accounts for the other two morphodynamic processes driving the high longshore sediment transport magnitudes. It should be emphasized that longshore sediment transport magnitudes are strongly dependent on the height of the dominant approaching waves and the orientation of the coast relative to the wave direction (shore-normal direction). The LSTR is maximized for a coast where the angle of wave incidence is around $45^{\circ}$ [18]. Contrary to this, a larger angle of incidence results in a decrease in the LSTR magnitude. Wave analysis for the two study areas indicated a wave incidence ranging between $10^{\circ}$ and $20^{\circ}$. Furthermore, the angle of the wave approach to the coastline is almost constant throughout the year for both estuaries. This confirms the influence of the prevailing wave conditions the high longshore sediment transport magnitudes recorded at the two study areas.

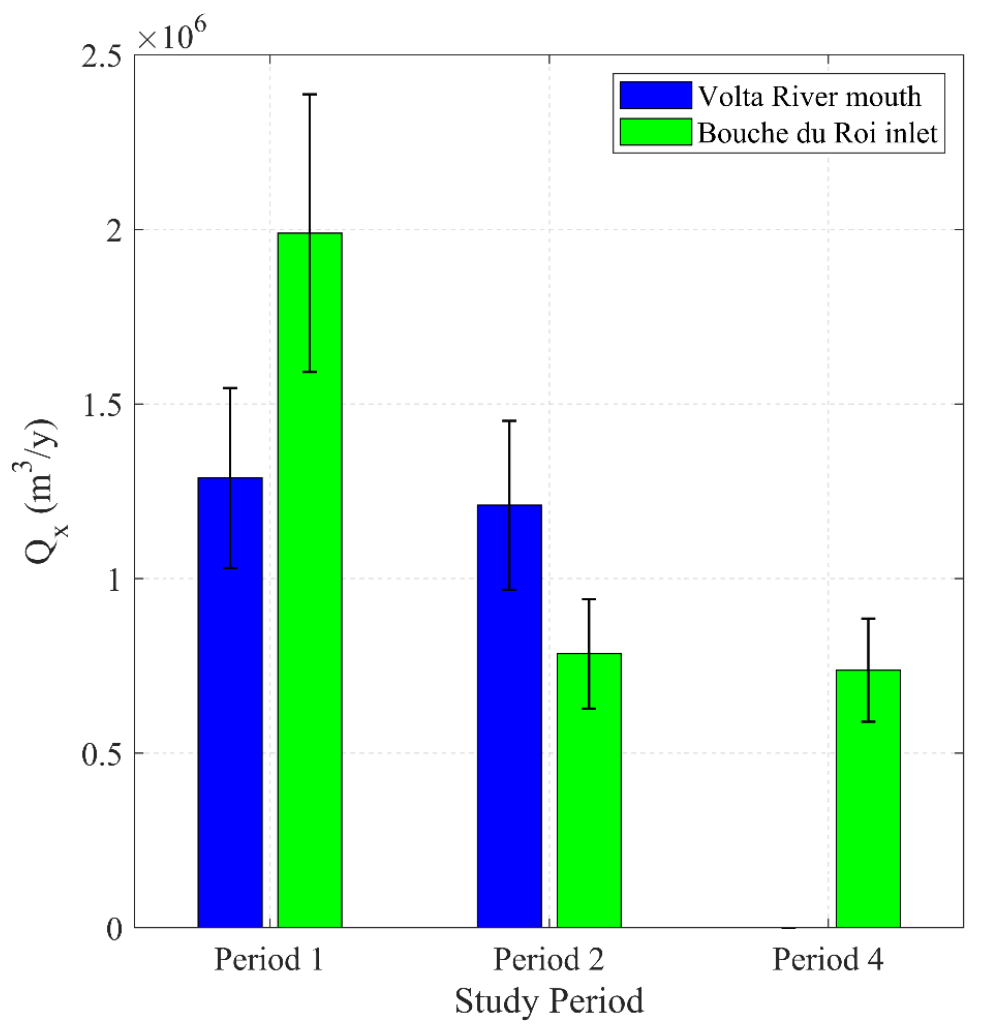

Figure 17. Estimated longshore sediment transport captured by the sandspits at the Volta River mouth, Ghana (blue), and the Bouche du Roi inlet, Benin (green), with its error margins (black).

From the LSTR results obtained, a comparative study was conducted to assess the difference in magnitudes of other estuaries and sandy beaches in the world. Information on the LSTR, depth of closure and berm elevation for other estuaries and sandy coasts was collected from multiple sources and used in the comparative study. For study areas where 
data on berm elevation were inaccessible, Equation (4) was applied to obtain an estimate. It is worth pointing out that the datasets for the USA are composed of measurements for both tidal inlets and sandy beaches. Additionally, the datasets obtained for Japan correspond entirely to measured data along sandy beaches. For Vietnam, all datasets represent investigations conducted at tidal inlets. The sources for the datasets used in the comparative study are presented in Table 5. Even though the methodology applied in our study differs from most of the datasets presented in Table 5, previous studies have shown that irrespective of the LSTR estimation method applied, the magnitude of the LSTR remains constant in most cases $[17,45,62]$. As such, the comparative study conducted here focused solely on the LSTR magnitudes of different geological settings.

Table 5. Sources of depth of closure, berm elevation and longshore sediment transport datasets for coastal areas used in the comparative study.

\begin{tabular}{|c|c|c|c|}
\hline Study Area & $D_{C}(\mathrm{~m})$ & $D_{B}(\mathrm{~m})$ & LSTR (m³/year) \\
\hline \multicolumn{4}{|c|}{ Africa } \\
\hline Alexandria coast, Egypt & Frihy et al. [63] & Equation (4) & Frihy et al. [63] \\
\hline Macaneta spit, Mozambique & Palalane et al. [64] & Palalane et al. [64] & Viola et al. [65] \\
\hline Sangomar spit, Senegal & Dennis et al. [66] & Palalane et al. [57] & Palalane et al. [57] \\
\hline \multicolumn{4}{|c|}{ Europe } \\
\hline Badreveln spit, Sweden & Hoan et al. [56] & Hoan et al. [56] & Hoan et al. [56] \\
\hline Sahalin spit, Romania & Dan et al. [67] & Equation (4) & Dan et al. [67] \\
\hline \multicolumn{4}{|c|}{ North America } \\
\hline USA & USACE [68] & Equation (4) & USACE [46] \\
\hline \multicolumn{4}{|c|}{ South America } \\
\hline Balneario Solis, Uruguay & Alonso et al. [69] & Alonso et al. [69] & Alonso et al. [69] \\
\hline \multicolumn{4}{|c|}{ Asia } \\
\hline \multirow[b]{2}{*}{ Vietnam } & Uda [51] & $\begin{array}{c}\text { Equation (4) } \\
\text { Duc Anh et al. }\end{array}$ & Uda [51] \\
\hline & & $\begin{array}{c}\text { Duc Anh et al. [58], } \\
\text { Duy et al. [59], } \\
\text { Duc Anh et al. [60] }\end{array}$ & \\
\hline \multicolumn{4}{|c|}{ Oceania } \\
\hline Gold Coast, Australia & Splinter et al. [70] & Equation (4) & Splinter et al. [70] \\
\hline
\end{tabular}

The relationship between the LSTR $\left(Q_{x}\right)$ and the depth of active sediment motion $(D)$ is illustrated in Figure 18. This figure also shows the contour lines for the change rate coefficient $(\alpha)$ from Equation (15). The log-log plot of the $Q_{x}-D$ relationship provides a simple way to compare morphodynamic conditions among different coastal areas. In Figure 18, the depth of active sediment motion values for the various estuaries and sandy beaches range between 5 and $17 \mathrm{~m}$. Interestingly, the magnitudes of the LSTR significantly vary within this range, with no correlation with a high or low depth of active sediment motion. This finding could indicate that the prevailing hydrodynamic conditions at these estuaries and beaches mainly account for the differences in the LSTR magnitudes. From the selected estuaries and sandy beaches, it is observed from the LSTR for the Bight of Benin that it is one of the coastal areas in the world with an LSTR of a high magnitude. Hence, to tackle the chronic erosion being witnessed along this coast, a coordinated coastal management plan among countries in the Bight of Benin is required to appropriately capture this high amount of transported sediment. 


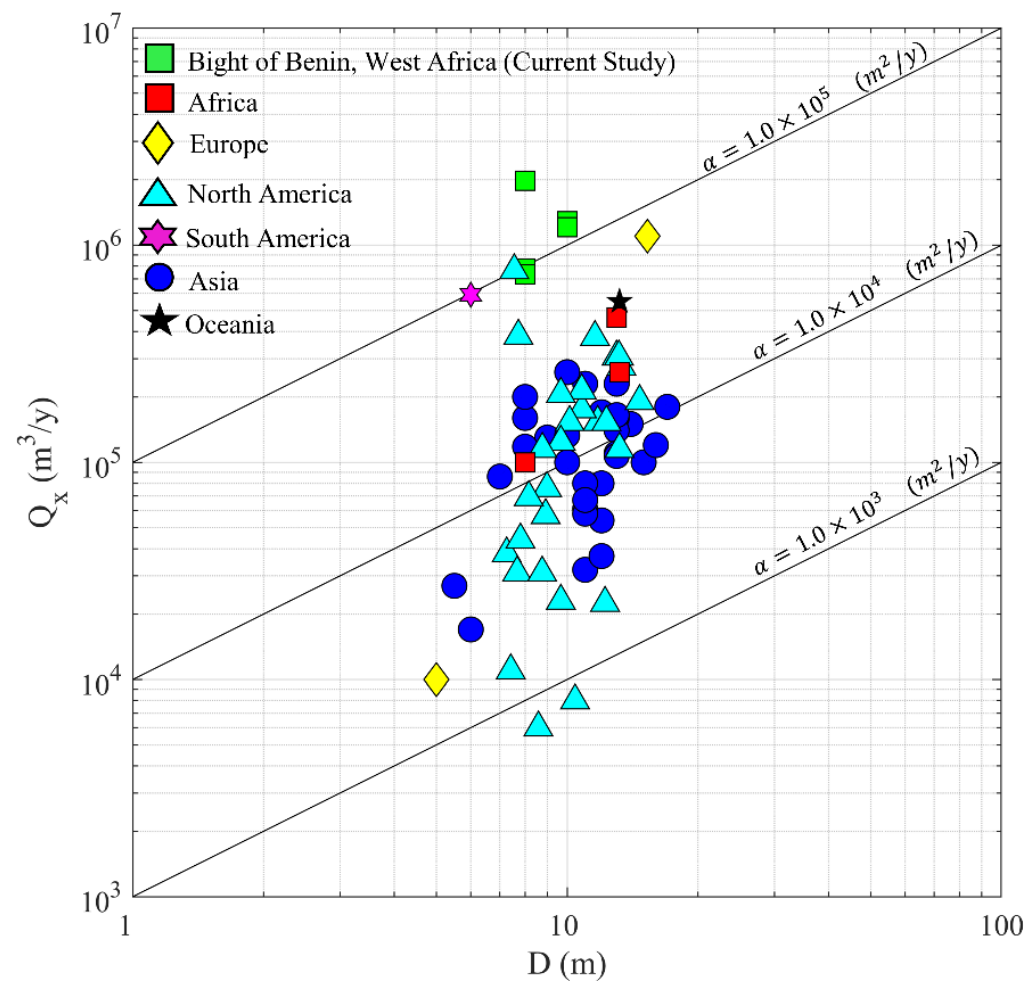

Figure 18. Comparison of the LSTR for the Bight of Benin with that of other estuaries and sandy coasts.

\subsection{Impact of Dam and Coastal Management on Estuarine Morphology}

In this section, the influence of engineering works executed in the upstream and downstream sections of the Volta River and Mono River is discussed. The construction of dams and shore protection infrastructure undoubtedly alters morphological and environmental patterns at estuaries. Underemphasizing the impact of these alterations could result in extreme cascading effects beyond a natural or artificial recovery process. The Akosombo, Kpong and Nangbeto dams have greatly improved the social well-being and industrialization process in Ghana, Togo, Benin and other neighboring West African countries. Over the years, substantial studies have been carried out to evaluate the impacts of dam construction on estuarine communities of the Volta and Mono Rivers. Additionally, shore protection infrastructure, artificial sandspit breaching and estuary dredging are some common coastal management activities executed in the Bight of Benin coast. These are implemented as mitigation measures for the incessant beach erosion and coastal flooding plaguing this coast. We therefore discuss the impact of these countermeasures on estuarine morphological changes.

Regarding the Volta River, the pre-Akosombo and Kpong dam construction period was marked by high annual river discharges which inhibited the rapid growth of the estuarine sandspit [71]. In the absence of a rapidly elongating sandspit, efficient tidal exchange can be guaranteed depending on the prevailing hydrodynamic conditions. However, the low annual river discharges characterized by the post-dam construction on the Volta River resulted in rapid sandspit growth [71]. This can be confirmed by the growth rates estimated from the current study. Inefficient tidal exchange at the estuary provided a conducive environment for the breeding of freshwater snails, consequently leading to a high prevalence of schistosomiasis among communities in the estuaries [72]. According to Sokolow et al. [73], surges in schistosomiasis in the Volta basin after dam construction show a link between water development projects and the prevalence of schistosomiasis. This is further supported by the fact that in sub-Saharan Africa, dam construction and irrigation schemes continue to enhance potential transmission sites for schistosomiasis [73]. To increase saltwater intrusion into the estuary, artificial breaching of the sandspits was 
undertaken in 1990, 1996, 2003 and 2009 [53]. A permanent solution has been implemented through the construction of the jetty as part of the ASDP to restrict the elongation of the updrift sandspit. At the time of writing this paper, no studies have been found to ascertain the prevalence rate of schistosomiasis at the estuary after construction of the jetty. The postASDP period has been marked by intrusion of the sandspit into the estuary, as highlighted in Section 3.1.4. Before construction of the ASDP, the river mouth width was $457 \mathrm{~m}$ in December 2011. Post-ASDP measurements revealed that the river mouth width increased to about $1948 \mathrm{~m}$ in November 2016. However, measurements of the river mouth width in May 2020 revealed a river mouth width of about $1064 \mathrm{~m}$. The decrease in the river mouth width can be attributed to the intrusion of both sandspits into the estuary. As such, the intrusion of the sandspits could result in the initial problem of a narrow river mouth and inefficient tidal exchange at the estuary.

The Bouche du Roi inlet was analyzed in this study as a case of a tidal inlet with its morphological evolution critically affected by alterations in updrift areas. Localized engineering activities around the inlet have also impacted the morphology of the estuary. The large-scale Nangbeto dam has been extremely beneficial to both Togo and Benin in terms of socio-economic development. As with Ghana, the schistosomiasis prevalence in both countries has been described as an endemic [74]. In a study by [73] to assess dam construction in sub-Saharan Africa and its influence on schistosomiasis cases, a drastic increase in cases was recorded. The study included both the Volta and Mono basins among other African basins. Hence, the association between dam construction and its influence on schistosomiasis infection rates in this region is a typical case where engineering works have resulted in unintended environmental and health issues. With respect to floods, low discharges from the Mono River after dam construction have led to a decrease in the frequency of floods in the lagoon zone [75]. This could be acknowledged as a positive impact of the dam construction on the estuary system. However, the effect of the reduced river sediment supply to the estuary system cannot be overlooked. Shoreline analysis by Anthony et al. [76] revealed severe shoreline retreat around the Bouche du Roi inlet between 2000 and 2005 and 2010 and 2015. This was attributed to the reduction in river sediment supply from the Mono River and the periodic breaching of the sandspit. Generally, intense coastal erosion is witnessed in the downdrift section of the Volta River mouth, with erosion hotspots being the eastern coast of Ghana, Togo, Benin and Nigeria. The reduction in river sediment supply from the Volta River has been identified as one of the factors influencing this condition [34]. In addition, the capture of longshore sediment transport by shore protection structures and ports along the Bight of Benin coast has exacerbated erosion rates along the coast [39].

In summary, the reduction in river discharge due to damming on the Volta and Mono Rivers has steered the rapid growth of estuarine sandspits through the accretion of longshore sediment. Additionally, the decline in the annual river sediment supply into the Bight of Benin coast from the Volta and Mono rivers has severely disrupted the sediment budget along the coast. This has therefore intensified erosion rates along the coast. Furthermore, the uncoordinated construction of shore protection structures and seaports is among the major factors driving high erosion rates along the Bight of Benin coast. The way forward to saving the remaining coastal communities and coastlines would require the creation of a coordinated and integrated coastal development plan among countries in the Bight of Benin that ensures in-depth environmental impact assessment of coastal projects to prevent unwarranted cascading effects in downdrift areas. The adoption of such a plan would also ensure the protection of coastal communities in the Bight of Benin and consequently promote other socio-economic activities such as fishing, tourism, navigation and agriculture.

\section{Conclusions}

The findings of this study contribute to the understanding of estuarine morphodynamic processes at the Volta River mouth (Ghana) and the Bouche du Roi inlet (Benin), 
along the Bight of Benin coast in West Africa. Freely available remotely sensed images were used to quantify sandspit growth and longshore sediment transport rates by applying a simple analytical model based on the conservation of sand volume. Estimates of longshore sediment transport along this coast were in the order of $10^{5}-10^{6} \mathrm{~m}^{3} /$ year. In addition, our comparative analysis of the LSTR for the study areas examined to that of estuaries and sandy coasts from previous studies revealed that the LSTR for the Bight of Benin has one of the largest magnitudes in the world. Sediment sourced from the Volta River, the low angle of wave incidence and the constant angle of the wave approach to the coastline throughout the year are among the main factors influencing the high magnitude of the LSTR in the Bight of Benin coast. Anthropogenic activities within and beyond estuarine systems have directly or indirectly resulted in significant changes at the estuaries considered in this study. Findings from previous studies and the current study have revealed that dam construction coupled with shore protection structures along the Bight of Benin coast has altered the coastal morphodynamics and the evolution of the estuaries considered in this study. Rapid elongation of estuarine sandspits, sandspit intrusion, downdrift erosion and increased prevalence of schistosomiasis are among some changes ensuing in and around these estuaries. The results obtained for the updrift Volta River mouth and the downdrift Bouche du Roi inlet show the implications of uncoordinated coastal management within the Bight of Benin. The implementation of a unified coastal management plan or manual for this coast would be a step closer to solving the chronic beach erosion and other estuarine-related problems in West Africa. The findings from this study could support the development of such a coastal management plan for the Bight of Benin in the future by government authorities along this coast.

Author Contributions: Conceptualization, S.K.L. and H.T.; methodology, S.K.L. and N.T.H.; formal analysis, S.K.L., H.T. and N.T.H.; investigation, S.K.L.; data curation, S.K.L.; writing-original draft preparation, S.K.L.; writing-review and editing, H.T., K.U. and N.X.T.; visualization, S.K.L.; supervision, H.T., K.U. and N.X.T.; funding acquisition, H.T. All authors have read and agreed to the published version of the manuscript.

Funding: This research was funded under the Tohoku University-Tsinghua University Collaborative Research Fund (2020 to 2021).

Institutional Review Board Statement: Not applicable.

Informed Consent Statement: Not applicable.

Data Availability Statement: Datasets utilized in this study are contained within the article. Further data requests should be addressed to the corresponding author or hitoshi.tanaka.b7@dc.tohoku.ac.jp.

Acknowledgments: The authors would like to express their utmost appreciation for the financial support from the Tohoku University-Tsinghua University Collaborative Research Fund (2020 to 2021). S.K.L. appreciates the sponsorship from the Japanese Government Ministry of Education, Culture, Sports, Science and Technology (MEXT) Scholarship Program. The authors also appreciate the efforts of the Global Runoff Data Centre, 56068 Koblenz, Germany, and the Volta River Authority, Accra, Ghana, for providing relevant data for this study.

Conflicts of Interest: The authors declare no conflict of interest.

\section{References}

1. Gill, J.A.; Norris, K.; Potts, P.M. The buffer effect and large-scale population regulation in migratory birds. Nature 2001, 412, 436-438. [CrossRef] [PubMed]

2. Halpern, B.S.; Walbridge, S.; Selkoe, K.A.; Kappel, C.V.; Micheli, F.; D’Agrosa, C.; Bruno, J.F.; Casey, K.S.; Ebert, C.; Fox, H.E.; et al. A global map of human impact on marine ecosystems. Science 2008, 319, 948-952. [CrossRef]

3. Barbier, E.B.; Hacker, S.D.; Kennedy, C.; Koch, E.W.; Stier, A.C.; Silliman, B.R. The value of estuarine and coastal ecosystem services. Ecol. Monogr. 2011, 81, 69-193. [CrossRef]

4. Hibma, A.; Stive, M.J.F.; Wang, Z.B. Estuarine morphodynamics. Coast. Eng. 2004, 51, 765-778. [CrossRef]

5. Karunarathna, H.; Reeve, D.; Spivack, M. Long-term morphodynamic evolution of estuaries: An inverse problem. Estuar. Coast. Shelf Sci. 2008, 77, 385-395. [CrossRef] 
6. Wang, Z.B.; Van Maren, D.S.; Ding, P.X.; Yang, S.L.; Van Prooijen, B.C.; De Vet, P.L.M.; Winterwerp, J.C.; De Vriend, H.J.; Stive, M.J.F.; He, Q. Human impacts on morphodynamic thresholds in estuarine systems. Cont. Shelf. Res. 2015, 111, 174-183. [CrossRef]

7. Dam, G.; Van Der Wegen, M.; Labeur, R.J.; Roelvink, D. Modeling centuries of estuarine morphodynamics in the Western Scheldt estuary. Geophys. Res. Lett. 2016, 43, 3839-3847. [CrossRef]

8. Luan, H.L.; Ding, P.X.; Wang, Z.B.; Ge, J.Z. Process-based morphodynamic modeling of the Yangtze Estuary at a decadal timescale: Controls on estuarine evolution and future trends. Geomorphology 2017, 290, 347-364. [CrossRef]

9. Xie, D.; Gao, S.; Wang, Z.B.; Pan, C.; Wu, X.; Wang, Q. Morphodynamic modeling of a large inside sandbar and its dextral morphology in a convergent estuary: Qiantang Estuary, China. J. Geophys. Res. Earth Surf. 2017, 122, 1553-1572. [CrossRef]

10. Yuan, B.; Sun, J.; Lin, B.; Zhang, F. Long-term morphodynamics of a large estuary subject to decreasing sediment supply and sea level rise. Glob. Planet Chang. 2020, 191, 103212. [CrossRef]

11. Wang, Z.B.; Hoekstra, P.; Burchard, H.; Ridderinkhof, H.; De Swart, H.E.; Stive, M.J.F. Morphodynamics of the Wadden Sea and its barrier island system. Ocean Coast. Manag. 2012, 68, 39-57. [CrossRef]

12. Teodoro, A.C.; Taveira-Pinto, F.; Santos, I. Morphological and statistical analysis of the impact of breakwaters under construction on a sand spit area (Douro River estuary). J. Coast. Conserv. 2014, 18, 177-191. [CrossRef]

13. Chen, Z.; Xu, H.; Wang, Y. Ecological degradation of the Yangtze and Nile delta-estuaries in response to dam construction with special reference to monsoonal and arid climate settings. Water 2021, 13, 1145. [CrossRef]

14. Zheng, S.; Cheng, H.; Lv, J.; Li, Z.; Zhou, L. Morphological evolution of estuarine channels influenced by multiple anthropogenic stresses: A case study of the North Channel, Yangtze estuary, China. Estuar. Coast. Shelf Sci. 2021, 249, 107075. [CrossRef]

15. Pradhan, U.; Mishra, P.; Mohanty, P.K.; Behera, B. Formation, growth and variability of sand spit at Rushikulya River Mouth, South Odisha Coast, India. Proc. Eng. 2015, 116, 963-970. [CrossRef]

16. Tanaka, H.; Nguyen, T.T.; Wada, N. Laboratory study of sand bar development at a river entrance. In Proceedings of the XXXI IAHR Congress, Seoul, Korea, 11-16 September 2005; pp. 3778-3787.

17. Dan, S.; Walstra, D.J.R.; Stive, M.J.F.; Panin, N. Processes controlling the development of a river mouth spit. Mar. Geol. 2011, 280, 116-129. [CrossRef]

18. Petersen, D.; Deigaard, R.; Fredsøe, J. Modelling the morphology of sandy spits. Coast. Eng. 2008, 55, 671-684. [CrossRef]

19. Ryabchuk, D.; Leont'yev, I.; Sergeev, A.; Nesterova, E.; Sukhacheva, L.; Zhamoida, V. The morphology of sand spits and the genesis of longshore sand waves on the coast of the eastern Gulf of Finland. Baltica 2011, 24, 13-24.

20. Nurfaida, W.; Sato, S. A study on hydrodynamic characteristics and resulting morphological formation of sand spit around the Tenryu river mouth based on image analysis. Proc. Eng. 2015, 116, 141-148. [CrossRef]

21. Hiep, N.T.; Tanaka, H.; Tinh, N.X. Morphology recovery of the Abukuma River mouth after the 2011 Tohoku tsunami under the interaction between sand spit and sand terrace. Coast. Eng. J. 2021, 1-18. [CrossRef]

22. Escudero, M.; Silva, R.; Hesp, P.A.; Mendoza, E. Morphological evolution of the sandspit at Tortugueros Beach, Mexico. Mar. Geol. 2019, 407, 16-31. [CrossRef]

23. Xie, D.; Pan, C. Morphodynamics of sandbar in a macro-tidal estuary: A model approach. Proc. Eng. 2012, 37, 328-332. [CrossRef]

24. Watanabe, S.; Uda, T.; Serizawa, M.; Miyahara, S. Numerical Simulation of Elongation and Merging of Bay Mouth Sand Spits Using the Bg Model. Coast. Eng. Proc. 2014, 1, 4. [CrossRef]

25. Lisboa, P.V.; Fernandes, E.H. Anthropogenic influence on the sedimentary dynamics of a sand spit bar, Patos Lagoon Estuary, RS, Brazil. J. Integr. Coast. Zone Manag. 2015, 15, 35-46. [CrossRef]

26. Miyahara, S.; Uda, T.; Serizawa, M.; San-Nami, T. Elongation of sand spit and profile changes on sloping shallow seabed. Proc. Eng. 2015, 116, 245-253. [CrossRef]

27. Nienhuis, J.H.; Ashton, A.D.; Nardin, W.; Fagherazzi, S.; Giosan, L. Alongshore Sediment Bypassing as a Control on River Mouth Morphodynamics. J. Geophys. Res. Earth Surf. 2016, 121, 664-683. [CrossRef]

28. Uda, T.; Serizawa, M.; Miyahara, S. Formation of Sand Spit and Bay Barrier. In Morphodynamic Model for Predicting Beach Changes Based on Bagnold's Concept and Its Applications; IntechOpen: London, UK, 2018; pp. 103-130. [CrossRef]

29. Bolle, A.; Das Neves, L.; Rooseleer, J. Coastal protection for ada, Ghana: A case study. Coastal Management: Changing coast, changing climate, changing minds. In Proceedings of the Institution of Civil Engineers Conference, Amsterdam, The Netherlands, 8-9 September 2015; Volume 168, pp. 501-511. [CrossRef]

30. Giardino, A.; Schrijvershof, R.; Nederhoff, C.M.; de Vroeg, H.; Brière, C.; Tonnon, P.K.; Caires, S.; Walstra, D.J.; Sosa, J.; van Verseveld, W.; et al. A quantitative assessment of human interventions and climate change on the West African sediment budget. Ocean Coast. Manag. 2018, 156, 249-265. [CrossRef]

31. Appeaning Addo, K.; Brempong, E.; Jayson-Quashigah, P.N. Assessment of the dynamics of the Volta river estuary shorelines in Ghana. Geoenviron. Disasters 2020, 7, 1-11. [CrossRef]

32. Guerrera, F.; Martín-Martín, M.; Tramontana, M.; Nimon, B.; Kpémoua, K.E. Shoreline changes and coastal erosion: The case study of the coast of Togo (Bight of Benin, West Africa margin). Geoscience 2021, 11, 40. [CrossRef]

33. Rossi, G. L'impact des barrages de la vallée du Mono (Togo-Benin). La gestion de l'incertitude. Géomorphol. Reli. Process. Environ. 1996, 2, 55-68. [CrossRef]

34. Ly, C.K. The role of the Akosombo Dam on the Volta river in causing coastal erosion in central and eastern Ghana (West Africa). Mar. Geol. 1980, 37, 323-332. [CrossRef] 
35. Anthony, E.J. Patterns of Sand Spit Development and Their Management Implications on Deltaic, Drift-Aligned Coasts: The Cases of the Senegal and Volta River Delta Spits, West Africa. In Sand and Gravel Spits; Randazzo, G., Jackson, D.W.T., Cooper, J.A.G., Eds.; Coastal Research Library; Springer International Publishing: Cham, Switzerland, 2015; pp. 21-36. [CrossRef]

36. Laibi, R.; Antoine, G.; Anthony, E.J.; Lucien-Marc, O. Apport Des Séries D’Images Landsat Dans L'Étude De La Dynamique Spatio-Temporelle De L'Embouchure De L'Estuaire Des Fleuves Mono Et Couffo Au Bénin, Avant Et Après La Construction Du Barrage De Nangbéto Sur Le Mono. Teledetection 2012, 10, 179-198. (In French)

37. Duc Anh, N.Q.; Tanaka, H.; Tam, H.S.; Tinh, N.X.; Tung, T.T.; Viet, N.T. Comprehensive Study of the Sand Spit Evolution at Tidal Inlets in the Central Coast of Vietnam. J. Mar. Sci. Eng. 2020, 8, 722. [CrossRef]

38. Amenuvor, M.; Gao, W.; Li, D.; Shao, D. Effects of dam regulation on the hydrological alteration and morphological evolution of the Volta River Delta. Water 2020, 12, 646. [CrossRef]

39. Allersma, E.; Tilmans, W.M.K. Coastal conditions in West Africa-A review. Ocean Coast. Manag. 1993, 19, 199-240. [CrossRef]

40. Anthony, E.J.; Lang, J.; Oyédé, L.M. Sedimentation in a tropical, microtidal, wave-dominated coastal-plain estuary. Sedimentology 1996, 43, 665-675. [CrossRef]

41. Rossi, G.; Blivi, A. Les conséquences des aménagements hydrauliques de la vallée du Mono (Togo-Bénin). Saura-t-on gérer l'avenir? Cah D'outre-Mer 1995, 48, 435-452. [CrossRef]

42. Vos, K.; Splinter, K.D.; Harley, M.D.; Simmons, J.A.; Turner, I.L. CoastSat: A Google Earth Engine-enabled Python toolkit to extract shorelines from publicly available satellite imagery. Environ. Model. Softw. 2019, 122, 104528. [CrossRef]

43. Vos, K.; Harley, M.D.; Splinter, K.D.; Simmons, J.A.; Turner, I.L. Sub-annual to multi-decadal shoreline variability from publicly available satellite imagery. Coast. Eng. 2019, 150, 160-174. [CrossRef]

44. Tanaka, H.; Kabutoyama, H.; Shuto, N. Numerical model for predicting the seasonal migration of a river mouth. WIT Trans. Built Environ. 1970, 10, 345-352. [CrossRef]

45. Kraus, N.C. Analytical Model of Spit Evolution at Inlets. In: Coastal Sediments 99, ASCE. In Proceedings of the 4th International Symposium of Coastal Engineering and Science of Coastal Sediment Processes, Long Island, NY, USA, 21-23 June 1999; pp. 1739-1754.

46. US Army Corps of Engineers. Part III-Chapter 2: Longshore Sediment Transport. In Coastal Engineering Manual; EM 1110-2-1100; US Army Corps of Engineers: Washington, DC, USA, 2002.

47. Hallermeier, R.J. Uses for a Calculated Limit Depth To Beach Erosion. In Coastal Eningeering, Proceedings of the 16th Conference on Coastal Engineering, Hamburg, Germany, 27 August-3 September 1978; ASCE: Reston, VA, USA, 1978; pp. 1493-1512. [CrossRef]

48. Hallermeier, R.J. A profile zonation for seasonal sand beaches from wave climate. Coast. Eng. 1981, 4, 253-277. [CrossRef]

49. Udo, K.; Ranasinghe, R.; Takeda, Y. An assessment of measured and computed depth of closure around Japan. Sci. Rep. 2020, 10, 2987. [CrossRef]

50. Razak, M.A.; Khan, A. Development of a Predictive Closure Depth Equation Using Field Data and Wave Refraction Modelling. IOP Conf. Ser. Mater. Sci. Eng. 2020, 849, 012093. [CrossRef]

51. Uda, T. Beach Erosion in Japan; Sankaido Press: Tokyo Japan, 1997; p. 242. (In Japanese)

52. Roest, L.W.M. The Coastal System of the Volta Delta, Ghana: Strategies and Opportunities for Development; TU Delft Delta Infrastures and Mobility Initiative (DIMI): Delft, The Netherlands, 2018.

53. Nyekodzi, G.; Lawson, E.T.; Gordon, C. Evaluating the impacts of dredging and saline water intrusion on rural livelihoods in the Volta Estuary. Int. J. River Basin Manag. 2018, 16, 93-105. [CrossRef]

54. Hiep, N.T.; Tanaka, H.; Tinh, N.X. Centennial to Multi-Decadal Morphology Change and Sediment Budget Alteration with Consideration of the Impacts of the 2011 Tohoku Earthquake Tsunami along the Nobiru Coast, Japan. J. Mar. Sci. Eng. 2021, 9, 265. [CrossRef]

55. Tanaka, H.; Lee, H.S. Influence of jetty construction on morphology and wave set-up at a river mouth. Coast Eng. J. 2003, 45, 659-683. [CrossRef]

56. Hoan, L.X.; Hanson, H.; Larson, M.; Kato, S. A mathematical model of spit growth and barrier elongation: Application to Fire Island Inlet (USA) and Badreveln Spit (Sweden). Estuar. Coast Shelf Sci. 2011, 93, 468-477. [CrossRef]

57. Palalane, J.; Larson, M.; Hanson, H. Analytical Model of Sand Spit Evolution. Coast. Eng. Proc. 2014, 1, 72. [CrossRef]

58. Duc Anh, N.Q.; Tanaka, H.; Tinh, N.X.; Viet, N.T. Sand spit morphological evolution at tidal inlets by using satellite images analysis: Two case studies in Vietnam. J. Sci. Technol. Civ. Eng. NUCE 2020, 14, 17-27. [CrossRef]

59. Duy, D.V.; Tanaka, H.; Mitobe, Y.; Anh, N.Q.D.; Viet, N.T. Sand Spit Elongation and Sediment Balance at Cua Lo Inlet in Central Vietnam. J. Coast. Res. 2018, 81, 32. [CrossRef]

60. Duc Anh, N.Q.; Duy, D.V.; Tanaka, H.; Viet, N.T. Elongation of sand spit at Loc An river mouth, Southern Vietnam. J. JSCE Ser. B3 (Ocean Eng.) 2018, 74, I_695-I_700. [CrossRef]

61. Taveneau, A.; Almar, R.; Bergsma, E.W.J.; Sy, B.A.; Ndour, A.; Sadio, M.; Garlan, T. Observing and Predicting Coastal Erosion at the Langue de Barbarie Sand Spit around Saint Louis (Senegal, West Africa) through Satellite-Derived Digital Elevation Model and Shoreline. Remote Sens. 2021, 13, 2454. [CrossRef]

62. Almar, R.; Kestenare, E.; Reyns, J.; Jouanno, J.; Anthony, E.J.; Laibi, R.; Hemer, M.; Du Penhoat, Y.; Ranasinghe, R. Response of the Bight of Benin (Gulf of Guinea, West Africa) coastline to anthropogenic and natural forcing, Part1: Wave climate variability and impacts on the longshore sediment transport. Cont. Shelf Res. 2015, 110, 48-59. [CrossRef] 
63. Frihy, O.E.; Iskander, M.M.; Badr, A.E.M.A. Effects of shoreline and bedrock irregularities on the morphodynamics of the Alexandria coast littoral cell, Egypt. Geo-Mar. Lett. 2004, 24, 195-211. [CrossRef]

64. Palalane, J.; Larson, M.; Hanson, H. Modeling Dune Erosion, Overwash, and Breaching at Macaneta Spit, Mozambique. In Coastal Sediments 2015, Proceedings of the 8th International Symposium on Coastal Sediment Process, San Diego, CA, USA, 11-15 May 2015; Wang, P., Rosati, D., Cheng, J., Eds.; World Scientific: Singapore; Toh Tuck Link: Singapore, 2015.

65. Viola, C.N.A.; Grifoll, M.; Palalane, J.; Oliveira, T.C.A. Sea wave propagation from offshore to Maputo's coast. Application to longshore sediment transport assessment. Water Sci. Technol. 2014, 69, 2438-2445. [CrossRef]

66. Dennis, K.C.; Niang-Diop, I.; Nicholls, R.J. Sea-Level Rise and Senegal: Potential Impacts and Consequences. J. Coast. Res. 1995, 14, 243-261.

67. Dan, S.; Stive, M.; Walstra, D.J.; Sabatier, F. Sediment budget of the danube delta coastal zone. In Coast Sediments '07. Proceedings of the 6th International Symposium on Coastal Engineering and Science of Coastal Sediment Process, New Orleans, LA, USA, 13-17 May 2007; ASCE: Reston, VA, USA, 2007.

68. Coastal Inlet Research Program; US Depth of Closure Information. Available online: https://cirp.usace.army.mil/products/ depth-of-closure.php (accessed on 12 July 2021).

69. Alonso, R.; López, G.; Mosquera, R.; Solari, S.; Teixeira, L. Coastal erosion in Balneario Solís, Uruguay. J. Coast Res. 2014, 71, 48-54. [CrossRef]

70. Splinter, K.D.; Golshani, A.; Stuart, G.; Tomlinson, R. Spatial and Temporal Variability of Longshore Transport along Gold Coast, Australia. In Coastal Engineering, Proceedings of the 32nd Conference on Coastal Engineering, Shanghai, China, 30 June-5 July 2010; Smith, J.M., Lynett, P., Eds.; ICCE: Los Angeles, CA, USA, 2010. [CrossRef]

71. Gordon, C.; Amatekpor, J.K. (Eds.) The Sustainable Integrated Development of the Volta Basin in Ghana; Volta Basin Research Project: Accra, Ghana, 1999; p. 159.

72. Zakhary, K. Factors affecting the prevalence of schistosomiasis in the Volta region of Ghana. McGill J. Med. 1997, 3, 93-101. [CrossRef]

73. Sokolow, S.H.; Jones, I.J.; Jocque, M.; La, D.; Cords, O.; Knight, A.; Lund, A.; Wood, C.L.; Lafferty, K.D.; Hoover, C.M.; et al. Nearly 400 million people are at higher risk of schistosomiasis because dams block the migration of snail-eating river prawns. Philos. Trans. R. Soc. B Biol. Sci. 2017, 372, 1-12. [CrossRef]

74. Onzo-Aboki, A.; Ibikounlé, M.; Boko, P.M.; Savassi, B.S.; Doritchamou, J.; Siko, E.J.; Daré, A.; Batcho, W.; Massougbodji, A.; Tougoue, J.J.; et al. Human schistosomiasis in Benin: Countrywide evidence of Schistosoma haematobium predominance. Acta Trop. 2019, 191, 185-197. [CrossRef]

75. Trebaol, L.; Chabal, J.P. EIA of the Adjarala hydroelectric project (Togo-Benin): The aquatic environment component. Afr. J. Environ. Assess. Manag. 2003, 5, 55-65.

76. Anthony, E.J.; Almar, R.; Besset, M.; Reyns, J.; Laibi, R.; Ranasinghe, R.; Abessolo Ondoa, G.; Vacchi, M. Response of the Bight of Benin (Gulf of Guinea, West Africa) coastline to anthropogenic and natural forcing, Part 2: Sources and patterns of sediment supply, sediment cells, and recent shoreline change. Cont. Shelf. Res. 2019, 173, 93-103. [CrossRef] 